\title{
WPS3576
}

\section{Poverty in Rural and Semi-Urban Mexico during 1992-2002}

\author{
By
}

\author{
Dorte Verner ${ }^{1}$ \\ Dverner@worldbank.org
}

\begin{abstract}
World Bank Policy Research Working Paper 3576, April 2005
The Policy Research Working Paper Series disseminates the findings of work in progress to encourage the exchange of ideas about development issues. An objective of the series is to get the findings out quickly, even if the presentations are less than fully polished. The papers carry the names of the authors and should be cited accordingly. The findings, interpretations, and conclusions expressed in this paper are entirely those of the authors. They do not necessarily represent the view of the World Bank, its Executive Directors, or the countries they represent. Policy Research Working Papers are available online at http://econ.worldbank.org.
\end{abstract}

${ }^{1}$ I am very grateful to Jose María Caballero for inviting me to write this paper and Mario Torres Falcon for excellent and invaluable research assistance. This paper complements a larger World Bank effort to understand poverty in Mexico, the so-called Mexico Programmatic Poverty Work. 


\section{Map 1. Regions of Mexico}

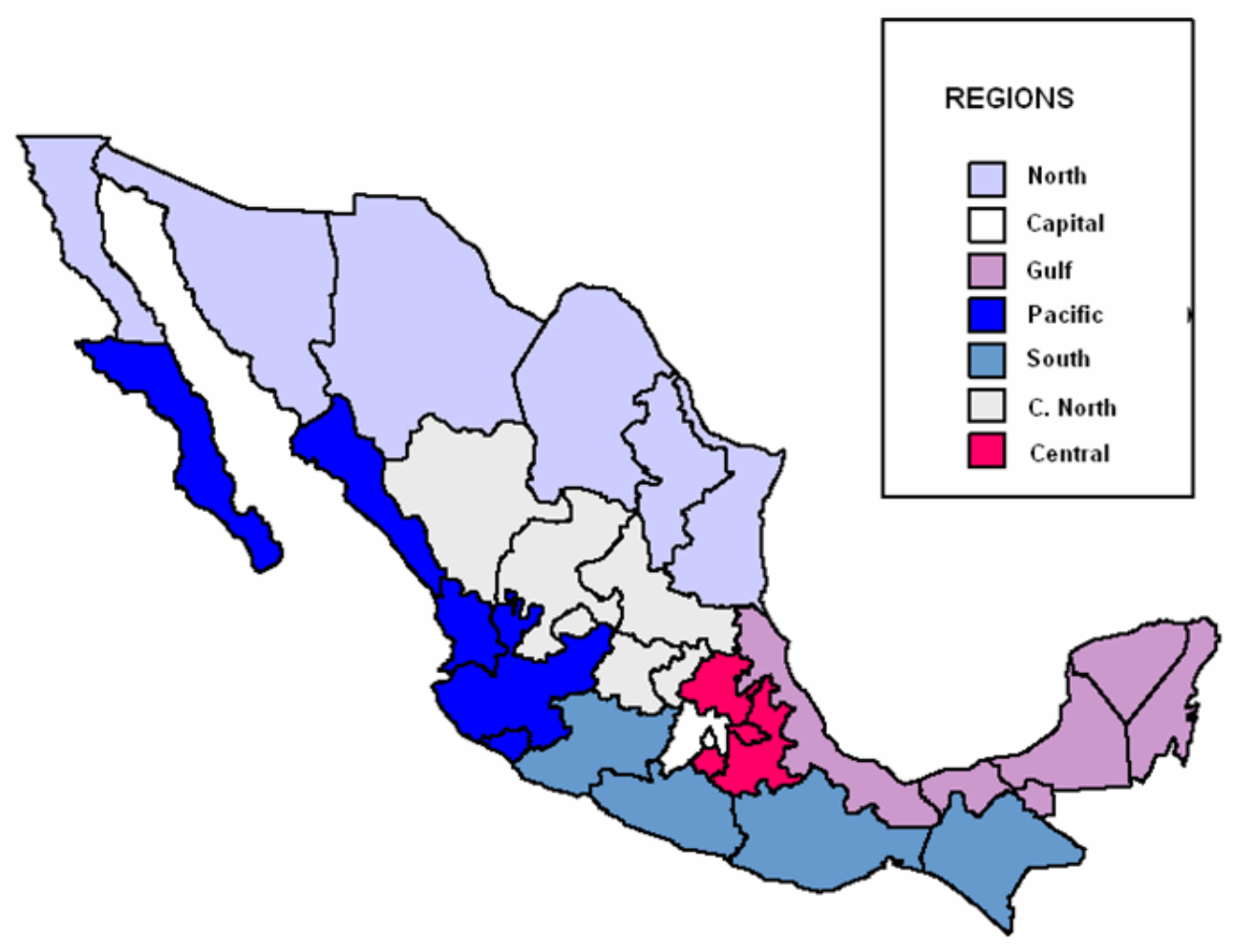




\begin{abstract}
This paper analyzes poverty in rural and semi-urban areas of Mexico (localities with less than 2,500 and 15,000 inhabitants, respectively) and it provides guidance on a social agenda and poverty alleviation strategy for rural Mexico. The analyses are based on INIGH and ENE datasets for 1992-2002. Monetary extreme poverty affected 42 percent of the rural population in dispersed rural areas and 21 percent in semi-urban areas in 2002, slightly less than one decade earlier. Most of the rural poor live in dispersed rural areas and 13.2 million people live in poverty in rural Mexico with less than 15,000 inhabitants. It is disproportionately a feature of households whose heads main job is in the agricultural sector, as self-employed farmers or rural laborers, and that have at most a primary education. However, the incidence of extreme rural poverty has declined since 1996 but at a slower pace than the decline in urban poverty. Hence, the rural-urban poverty gap increased in recent years and in some places extreme poverty is at least four times higher in rural than urban areas. Moreover, not only is the income gap in urban areas increasing, but also the gap between richer and poorer segments of the population in the rural areas is growing. Finally, the gap between rich and poor regions is still large.
\end{abstract}




\section{Introduction}

Rural poverty in Mexico is a subject of widespread interest. This is true within Mexico itself, but also in the broad American context as the rural population, for example, migrate and export their produce. There are some 25 million people in rural areas in Mexico, most of which are poor. The countryside has the greatest degree of poverty in Mexico, as is the case in most Latin American countries. Poverty in rural Mexico is not homogeneous, neither across time, regions nor across sectors, such as agricultural and off-farm sectors. Poverty is endemic in rural Mexico and affects particularly vulnerable groups, such as the indigenous populations.

Monetary extreme poverty affected 42 percent of the people in dispersed rural areas (localities with less than 2,500 inhabitants) and 21 percent in semi-urban rural areas (localities with less than 15,000 inhabitants) in 2002, slightly less than one decade earlier. Most of the rural poor (10.4 million) live in dispersed rural areas and some of the poor live in semi-urban areas (2.8 million). This translates into 13.2 million rural people living in poverty in rural Mexico with less than 15,000 inhabitants. It is disproportionately a feature of households with a head whose main job is in the agricultural sector, whether as a self-employed farmer or rural laborer, and has at most primary education. However, the incidence of extreme rural poverty has declined since 1996 but at a slower pace than the decline in urban poverty. ${ }^{2}$ Hence, the rural-urban poverty-gap increased in recent years and in some places extreme rural poverty is at least four times higher than in urban areas. Moreover, not only is the income gap to urban areas increasing but the gap between richer and poorer segments of the population in the rural areas is also growing. Finally, the gap between rich and poor regions is still large, such as between the North and South regions.

This paper attempts to analyze rural monetary poverty. Two definitions of rural areas are used: first, localities with more than 2,500 and less than 15,000 inhabitants refers to semi-urban areas; and, second, dispersed rural areas refers to localities with less than 2,500 in habitants (the official definition of rural in Mexico). The analyses are based on national household surveys (Encuesta nacional de Ingresos y Gastos de los HogaresENIGH) from 1992 to 2002.

The paper is organized in 6 sections. Section 2 presents demographics and their changes during 1970-2000 in terms of rural and urban population size. Furthermore, it shows the recent growth pattern for Mexico and its regions. Section 3 analyzes rural poverty and its depth during 1992-2002 and Section 4 shows the rural Mexican poverty profile. Section 5 presents analyses of determinants of poverty, important factors to

2 The Secretaria de Desarrollo Social (SEDESOL) uses three poverty lines: a "food-based" poverty line (income required to acquire enough food to cover nutritional needs); a "human needs" poverty line which includes also the income required to acquire basic education, health, housing, dress, footwear, and transportation; and an "assets-based" poverty line, which also includes other needs. The latter corresponds to the usual broad definition of "poverty", which we call "moderate poverty", while the former corresponds to the usual definition of "extreme poverty". 
escaping poverty and changes during 1992-2002. This section also addresses the extent to which the rural South region is different from rural Mexico as a whole. Finally, Section 6 presents a three-pronged rural poverty reduction strategy guided by the findings from the poverty profile and determinants of poverty analysis. The strategic principles for reducing poverty involve seeking to strengthen the key assets of the poor, taking into account geographic differences in the poverty situation and priorities.

\section{Populations and Land}

The degree of poverty a society might experience depends on the volume and distribution of resources and on the size and distribution of the population among households. These two basic determinants of poverty, however, are not independently determined. On one hand, the size and age structure of a population are consequences of fertility decisions taken over past decades that were influenced by economic conditions. On the other hand, the volume of resources available today is influenced by the size and age composition of the labor force. This section analyzes recent changes in demographics in Mexico's rural areas. The following section very briefly addresses agriculture, land, and rural living in Mexico.

\subsection{Population}

\section{The importance of demographic factors}

Demographic factors have direct and indirect impacts on prices and poverty. As the size and age composition of the population changes, the relative size of the labor force and the number of dependents also change, modifying the dependency ratio of families, and therefore their level of poverty. This is the direct effect of demographic changes. It captures the effect that demographic changes have on quantities: number of children, size of the labor force, and the number of elderly people. These changes in quantities, however, will, in general, influence prices in the economy. In particular, changes in the rate of growth of the population and in the age structure may have important impacts on labor supplies, savings, and household production decisions and migration. As a consequence, demographic changes may have considerable impact on the level of wages and on interest rates. Since these prices are important determinants of family income, they are bound to have a profound influence on the level of poverty. These are the indirect impacts of demographic changes on poverty, which occur through the effects of demographic changes on savings, wages, production decisions and interest rates.

Changing demographics can also have important impacts on the demand for public sector investments and public services, on incentives for private sector investments, on political power, and on labor markets. As a result, it is important to look at recent changes in demographic patterns in rural Mexico. The following overview describes demographic changes between rural and urban areas that have taken place from 1990 to 2000 followed by Section 3 on rural labor markets. 


\section{Overview of demographic changes in Mexico}

In 2000, 24.5 million of Mexican's total of 97.5 million people lived in dispersed rural areas, defined as localities with less than 2,500 inhabitants (Table 2.1 and Appendix A). Expanding the definition of rural to locations with less than 15,000 inhabitants, or semi-urban, increases the rural population to 38.1 million. In Mexico, the population is slowly moving to urban areas. In 2000, 25 percent of the Mexicans lived in rural areas, down from 29 percent one decade earlier. The rural population is not distributed equally across regions. For example, in the South region, nearly 50 percent of the population lives in rural areas, a total of more than 6.8 million people (Table 2.1).

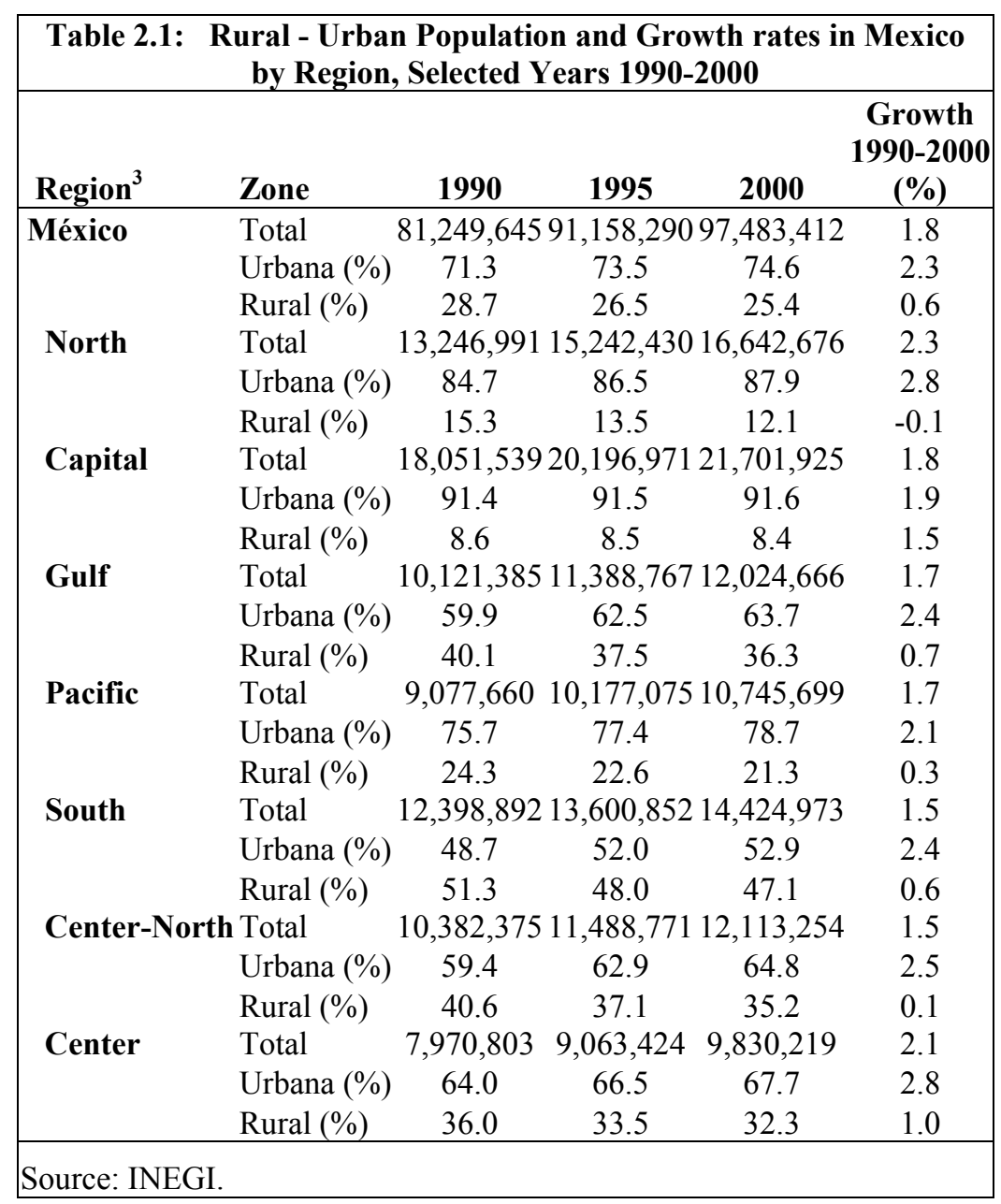

${ }^{3}$ The regions correspond to the following states: North: Baja California, Coahuila, Chihuahua, Nuevo Leon, Sonora, Tamaulipas; Capital: Distrito Federal, México; Gulf: Campeche, Quintana Roo, Tabasco, Veracruz, Yucatán; Pacific: BC South, Colima, Jalisco, Nayarit, Sinaloa; South: Chiapas, Guerrero, Michoacan, Oaxaca; Center-North: Aguascalentes, Durango, Guanajuato, Queretaro, San Luis Potosi, Zacatecas; Centro: Hidalgo, Morelos, Puebla, and Tlaxcala. 
Mexico's population increased from 66.9 million to 97.5 million during 19802000 or 1.8 percent per year (Table 2.2). In this period, Mexico has become more urbanized, and the largest population growth has taken place in urban areas. During the last two decades, Mexico's rural population has also increased. In 1980, rural Mexico with less than 15,000 inhabitants was home to 34.6 million people. In 2000, the rural population had increased to 38.1 million (Table 2.2). However, in rural areas, the population is expanding at a slower pace than the country as a whole, namely by 0.6 percent per year (Table 2.1). Not all regions follow the rural population growth pattern of the total country. In the North region, the rural population actually diminished by 0.1 percent annually during 1990-2000. In this period, in the Capital region, the difference in the population growth rate between rural and urban areas was the smallest in Mexico and the rural population expanded at 1.5 percent annually. The population growth rate in the poor South region and Gulf region followed closely the national average during the last decade.

\begin{tabular}{|c|c|c|c|c|c|c|c|}
\hline & $\begin{array}{c}\text { Less than } \\
2,500\end{array}$ & $\begin{array}{c}\text { Share } \\
(\%)\end{array}$ & $\begin{array}{c}\text { More than } \\
\mathbf{2 , 5 0 0}\end{array}$ & $\begin{array}{c}\text { Less than } \\
15,000\end{array}$ & $\begin{array}{c}\text { Share } \\
(\%)\end{array}$ & $\begin{array}{c}\text { More than } \\
15,000\end{array}$ & Total \\
\hline & \multicolumn{7}{|c|}{1980} \\
\hline Total Mexico & $22,547,104$ & 33.73 & $44,299,729$ & $32,242,146$ & 48.2 & $34,604,687$ & $66,846,833$ \\
\hline North & $2,360,814$ & 22.08 & $8,331,073$ & $3,317,815$ & 31.0 & $7,374,072$ & $10,691,887$ \\
\hline Capital & $1,556,931$ & 9.50 & $14,838,483$ & $3,115,882$ & 19.0 & $13,279,532$ & $16,395,414$ \\
\hline Gulf & $3,804,118$ & 46.61 & $4,356,794$ & $5,228,230$ & 64.1 & $2,932,682$ & $8,160,912$ \\
\hline Pacific & $2,332,162$ & 31.06 & $5,177,267$ & $3,602,773$ & 48.0 & $3,906,656$ & $7,509,429$ \\
\hline South & $5,557,813$ & 58.92 & $3,874,317$ & $7,259,617$ & 77.0 & $2,172,513$ & $9,432,130$ \\
\hline Center-North & $3,962,426$ & 47.98 & $4,295,771$ & $5,076,888$ & 61.5 & $3,181,309$ & $8,258,197$ \\
\hline Center & $2,972,840$ & 46.46 & $3,426,024$ & $4,640,941$ & 72.5 & $1,757,923$ & $6,398,864$ \\
\hline & \multicolumn{7}{|c|}{1990} \\
\hline Total Mexico & $23,289,924$ & 28.66 & $57,959,721$ & $34,574,235$ & 42.6 & $46,675,410$ & $81,249,645$ \\
\hline North & $2,032,682$ & 15.34 & $11,214,309$ & $3,035,755$ & 22.9 & $10,211,236$ & $13,246,991$ \\
\hline Capital & $1,552,489$ & 8.60 & $16,499,050$ & $2,961,367$ & 16.4 & $15,090,172$ & $18,051,539$ \\
\hline Gulf & $4,063,169$ & 40.14 & $6,058,216$ & $5,878,621$ & 58.1 & $4,242,764$ & $10,121,385$ \\
\hline Pacific & $2,207,351$ & 24.32 & $6,870,309$ & $3,657,722$ & 40.3 & $5,419,938$ & $9,077,660$ \\
\hline South & $6,354,957$ & 51.25 & $6,043,935$ & $8,670,353$ & 69.9 & $3,728,539$ & $12,398,892$ \\
\hline Center-North & $4,212,549$ & 40.57 & $6,169,826$ & $5,478,828$ & 52.8 & $4,903,547$ & $10,382,375$ \\
\hline Center & $2,866,727$ & 35.97 & $5,104,076$ & $4,891,589$ & 61.4 & $3,079,214$ & $7,970,803$ \\
\hline & \multicolumn{7}{|c|}{2000} \\
\hline Total Mexico & $24,723,590$ & 25.36 & $72,759,822$ & $38,064,204$ & 39.0 & $59,419,208$ & $97,483,412$ \\
\hline North & $2,015,059$ & 12.11 & $14,627,617$ & $3,153,993$ & 19.0 & $13,488,683$ & $16,642,676$ \\
\hline Capital & $1,812,596$ & 8.35 & $19,889,329$ & $3,645,216$ & 16.8 & $18,056,709$ & $21,701,925$ \\
\hline Gulf & $4,367,521$ & 36.32 & $7,657,145$ & $6,514,575$ & 54.2 & $5,510,091$ & $12,024,666$ \\
\hline Pacific & $2,290,394$ & 21.31 & $8,455,305$ & $3,865,830$ & 36.0 & $6,879,869$ & $10,745,699$ \\
\hline South & $6,791,721$ & 47.08 & $7,633,252$ & $9,579,248$ & 66.4 & $4,845,725$ & $14,424,973$ \\
\hline Center-North & $4,269,270$ & 35.24 & $7,843,984$ & $5,710,063$ & 47.1 & $6,403,191$ & $12,113,254$ \\
\hline Center & $3,177,029$ & 32.32 & $6,653,190$ & $5,595,279$ & 56.9 & $4,234,940$ & $9,830,219$ \\
\hline
\end{tabular}


The share of children in the total population is falling in rural Mexico. In 1980, children age 14 and under accounted for 43 percent of the total population in rural Mexico (Table 2.3). In 2000, the share of children age 14 and under was down to 34 percent. So far, the number of elderly dependents has not caught up with the reduction in children's share in the population. In 2000, only 5 percent of the population was 65 years of age or older (Table 2.3). This will have a significant effect on the country's efforts to reduce poverty. For the next few decades, the ratio of children to working age population will decline, while the number of retirees will remain small. As a result, not only will the dependency ratio fall, but also the amount the state must spend on expanding the quantity of social services will decline. This will free up resources to spend on improving quality of services and other rural poverty reduction efforts.

Table 2.3 also shows that there are regional differences in the aging pattern. In the rural South region more than 38 percent of the total population is 14 year of age or younger. This compares 30 percent in the rural North region. Moreover, there is a higher population share of working age and therefore able to better feed the region's children in the North compared to the South region. 


\begin{tabular}{|c|c|c|c|c|}
\hline & $\begin{array}{c}0-14 \\
\text { Years of age }\end{array}$ & $\begin{array}{c}15-44 \\
\text { Years of age }\end{array}$ & $\begin{array}{c}45-64 \\
\text { Years of age }\end{array}$ & $\begin{array}{c}65+ \\
\text { Years of age } \\
\end{array}$ \\
\hline & \multicolumn{4}{|c|}{1980} \\
\hline \begin{tabular}{|l} 
Total Mexico \\
North \\
Capital \\
Gulf \\
Pacific \\
Southr \\
Center North \\
Center \\
\end{tabular} & $\begin{array}{l}43.1 \\
41.9 \\
40.6 \\
42.9 \\
44.3 \\
44.7 \\
46.1 \\
44.3 \\
\end{array}$ & $\begin{array}{l}42.9 \\
43.9 \\
46.2 \\
43.0 \\
41.6 \\
41.2 \\
39.9 \\
40.9 \\
\end{array}$ & $\begin{array}{c}10.1 \\
10.5 \\
9.9 \\
10.3 \\
10.0 \\
10.2 \\
9.8 \\
10.5 \\
\end{array}$ & $\begin{array}{l}3.8 \\
3.7 \\
3.4 \\
3.8 \\
4.1 \\
3.9 \\
4.2 \\
4.2\end{array}$ \\
\hline Center & \multicolumn{4}{|c|}{1990} \\
\hline Total Mexico & 38.6 & 46.3 & 11.0 & 4.2 \\
\hline North & 35.4 & 49.0 & 11.5 & 4.0 \\
\hline Capital & 34.5 & 50.4 & 11.2 & 3.9 \\
\hline Gulf & 39.8 & 46.2 & 10.2 & 3.8 \\
\hline Pacific & 38.5 & 46.3 & 10.8 & 4.4 \\
\hline South & 43.0 & 42.2 & 10.6 & 4.2 \\
\hline Center-North & 41.3 & 43.8 & 10.5 & 4.3 \\
\hline \multirow[t]{2}{*}{ Center } & 44.2 & 11.0 & 4.5 & 4.5 \\
\hline & \multicolumn{4}{|c|}{2000} \\
\hline Total Mexico & 34.1 & 48.1 & 12.8 & 5.0 \\
\hline North & 32.3 & 50.1 & 13.0 & 4.6 \\
\hline Capital & 30.0 & 51.4 & 13.8 & 4.9 \\
\hline Gulf & 34.6 & 48.8 & 12.1 & 4.5 \\
\hline Pacific & 33.5 & 48.4 & 13.0 & 5.1 \\
\hline South & 38.4 & 44.4 & 12.0 & 5.2 \\
\hline Center-North & 36.5 & 46.4 & 12.0 & 5.1 \\
\hline Center & 35.2 & 46.9 & 12.5 & 5.4 \\
\hline
\end{tabular}

Fecundity, the number of children per mother, dropped from 2.8 in 1980 to 2.6 in 2000 in rural Mexico (Table 2.4). In the poor South region the fertility rate is still higher than in Mexico as a whole and the Capital region, namely by 0.3 percentage points and 0.7 percentage points, respectively. Women's increased participation in the labor market (by 3.3 percentage points see Table 2.5) may have been an important factor contributing to the reduction in the fertility rate and drop in the dependency rate. The female labor force participation rate is still lower in the South region (24.2 percent) than in the Capital region (35 percent) and therefore the high fertility rate in the former could be an important factor explaining this difference. Moreover, lack of access to childcare facilities etc. may also play a roll in the large difference in labor market structure among regions. 


\begin{tabular}{|l|cc|}
\hline \multicolumn{2}{|c|}{ Table 2.4: Fertility rate by region in rural Mexico, } \\
$\mathbf{1 9 8 0}$ and $\mathbf{2 0 0 0}$ \\
\hline Total Mexico & $\mathbf{1 9 8 0}$ & $\mathbf{2 0 0 0}$ \\
North & 2.8 & 2.6 \\
Capital & 2.8 & 2.5 \\
Gulf & 2.6 & 2.2 \\
Pacific & 2.7 & 2.5 \\
South & 3.0 & 2.7 \\
Center North & 2.8 & 2.9 \\
Center & 3.2 & 2.8 \\
\hline Source: Census 1980 and 2000. & 3.0 & 2.7 \\
\hline
\end{tabular}

The demographic change that demands the most urgent policy response is the growth in the economically active population in rural areas. During 1990-2000 the number of those aged 12 to 64 rose by more than 300,000 ( 0.6 percent). The growth rate is low primarily due to out-migration and some due to reduced fecundity. Migration is important in rural Mexico. Mostly young people leave their village in search of employment and find work in a wide variety of economic sectors, either in Mexico or the U.S.

\begin{tabular}{|l|c|c|c|c|}
\hline $\begin{array}{c}\text { Table 2.5: Female and male labor market participation } \\
\text { rate in Mexico, 1980 and 2000, Percent }\end{array}$ \\
\hline & \multicolumn{3}{|c|}{$\mathbf{1 9 8 0}$} & \multicolumn{2}{c|}{$\mathbf{2 0 0 0}$} \\
\hline & 75.2 & 26.5 & 70.2 & 29.8 \\
Total Mexico & 73.3 & 25.6 & 71.5 & 32.8 \\
North & 73.5 & 31.9 & 71.2 & 35.0 \\
Capital & 77.7 & 25.3 & 73.3 & 28.2 \\
Gulf & 74.3 & 23.6 & 71.6 & 32.2 \\
Pacific & 77.5 & 30.3 & 68.0 & 24.2 \\
South & 75.2 & 23.1 & 65.5 & 27.2 \\
Center North & 75.2 & 26.1 & 70.5 & 28.8 \\
Center & \multicolumn{5}{|l}{} \\
\hline Source: Census 1980 and 2000.
\end{tabular}

Poverty analyses reveal that many rural Mexican workers, particularly those in the informal sector and agriculture, are poor. The challenge of creating employment is therefore not only to provide new jobs for the new entrants to the labor force, but also to increase the number of jobs that are able to provide sufficient income to lift the employee's household out of poverty or cushion against it. Creating jobs regardless of quality is not enough-people need good jobs. As the labor market, particularly the informal one, is relatively flexible, the concern is about generating sufficient income via employment rather than simply having a job. The trend in this regard since 1999, as 
reflected by the recent increasing real wages of unskilled workers (with incomplete or no education) - is encouraging (Verner 2004).

\subsection{Agriculture, Land and Rural Living}

Although nearly half of Mexico's total land area is officially classified as agricultural, only 12 percent of the total area is cultivated. This is one of many factors driving migration and off-farm employment in rural Mexico. In the early 1990s, 80 percent of Mexico's cultivated land required regular irrigation. Because of the high cost of irrigation, the government has emphasized expanding production on existing farmland rather than expanding the area under irrigation. Although corn is grown on almost half of Mexico's cropland, the country became a net importer of grain during the 1970s.

Agricultural practices in Mexico range from traditional techniques, such as the slash-and-burn cultivation of indigenous plants for family subsistence, to the use of advanced technology and marketing expertise in large-scale, capital-intensive export agriculture. Government extension programs have fostered the wider use of machinery, fertilizers, and soil conservation techniques. These diverse agricultural practices call for a diverse rural labor market.

\section{Poverty}

Since 1996, Mexico has made creditable headway in reducing national poverty. During 1996-2002, the state's extreme poverty, measured by P0, fell 17 percentage points (Figure 3.1 and Table 3.1). ${ }^{4}$ There is little room for complacency, however, because extreme poverty was still only slightly lower in 2002 when 20 percent of the Mexicans were poorer than it was in 1992 (22 percent). This translates to around 20 million Mexicans who still live in extreme poverty, which means that they do not have sufficient income to buy a minimum basket of food.

Rural population is more affected than urban population by poverty. Extreme poverty affected 42 percent of the rural population in areas with less than 2,500 inhabitants in 2002, approximately the same as one decade earlier (Figure 3.1 and Table 3.1). While only 25 percent of Mexico's population lives in rural areas, more than 65 percent of the Mexican poor are live in rural areas. The incidence of extreme rural poverty has declined since 1996, but at a slower pace than the decline in urban poverty.

\footnotetext{
${ }^{4}$ Throughout this paper poverty refers to extreme poverty and poor to extremely poor. The secretariat of social development (Secretaria de Desarrollo Social-SEDESOL) uses three poverty lines: a "foodbased" poverty line (income required to acquire enough food to cover nutritional needs); a "human needs" poverty line which includes also the income required to acquire basic education, health, housing, dress, footwear, and transportation; and an "assets-based" poverty line, which also includes other needs. The latter corresponds to the usual broad definition of "poverty", which we call "moderate poverty', while the former corresponds to the usual definition of "extreme poverty" (World Bank 2004 for more information on poverty lines).
} 
Hence, the rural-urban poverty-gap has increased in recent years. Moreover, not only is the income gap to urban areas increasing but the gap between richer and poorer segments of the population in the rural areas is also growing. In 2002, rural Mexico had poverty rates for higher than urban Mexico. Dispersed rural areas had a poverty incidence double that of semi-urban areas. Furthermore, dispersed rural areas had a poverty incidence four times higher than urban areas in Mexico.

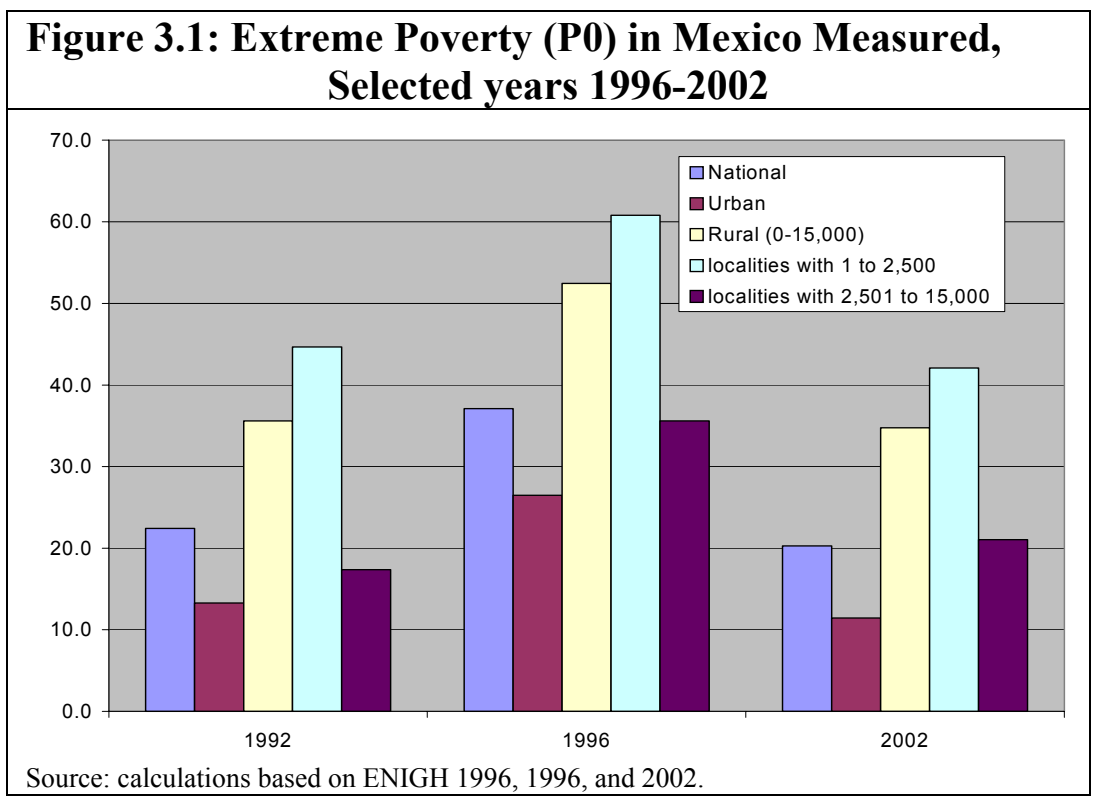

Mexico has steep gradients in conditions of living from more developed urban areas, through the urban periphery and smaller towns, through to the more remote rural areas. Figure 3.1 shows that this pattern has not changed much over the last decade and in rural localities with less than 2,500 people more than 40 percent were extremely poor compared with those localities with 2,500-15,000 people where 21 percent were poor in 2002. This translates into 13.2 million people in poverty. Most of the rural poor live in more dispersed rural areas, as 2.8 million were poor in semi-urban areas and 10.4 million poor in dispersed rural areas (information on population in rural areas in Appendix A).

Geographic factors are important when analyzing poverty in Mexico. Living in a poor area can make a profound difference to well-being and life prospects. There are large differences in income poverty between different regions, with a generalized gradient from North to South (Figure 3.2 and Table 3.1) ${ }^{5}$ In 2002, the headcount poverty rate in rural areas in the North region with less than 15,000 inhabitants reached 14 percent, a third of that in the South region where 48 percent were poor.

\footnotetext{
${ }^{5}$ ENIGH is not designed to be fully representative at regional level, but differences between regions are statistically significant (also Word Bank 2004).
} 
Table 3.1: Extreme poverty in Mexico and its regions, 1992-2002

\begin{tabular}{|c|c|c|c|c|c|}
\hline & $\begin{array}{c}\text { Headcount } \\
\text { (P0) }\end{array}$ & $\begin{array}{c}\text { Poverty Gap } \\
\text { (P1) }\end{array}$ & \multicolumn{3}{|c|}{$\begin{array}{c}\text { Square Poverty } \\
\text { Gap (P2) }\end{array}$} \\
\hline & 199219962002 & 199219962002 & 1992 & 1996 & 2002 \\
\hline National & $22.4 \quad 37.120 .3$ & $\begin{array}{|lll|}7.5 & 14.1 & 6.3\end{array}$ & 3.5 & 33.9 & 3.2 \\
\hline Urban & $\begin{array}{lll}13.3 & 26.5 & 11.4\end{array}$ & $\begin{array}{|lll|}3.6 & 8.3 & 2.8\end{array}$ & 1.4 & 3.7 & 1.1 \\
\hline Rural $(0-15,000)$ & $35.6 \quad 52.4 \quad 34.8$ & 13.122 .512 .2 & 6.5 & 77.5 & 6.6 \\
\hline Dispersed Rural (Localities with 1-2,500) & $44.7 \quad 60.8 \quad 42.1$ & $\begin{array}{lll}16.7 & 27.1 & 14.9\end{array}$ & 8.2 & 11.4 & 8.3 \\
\hline Semi-Urban (localities with $2,501-15,000$ ) & $17.4 \quad 35.6 \quad 21.1$ & $\begin{array}{lll}6.0 & 13.1 & 7.0\end{array}$ & 3.0 & 11.0 & 3.4 \\
\hline \multicolumn{6}{|l|}{ Region } \\
\hline \multicolumn{6}{|l|}{ North } \\
\hline Total & $9.4 \quad 22.0 \quad 6.4$ & $2.5 \quad 8.0 \quad 1.6$ & 1.1 & 159.5 & 2.2 \\
\hline Rural $(0-15,000)$ & $\begin{array}{lll}13.3 & 30.9 & 13.8\end{array}$ & $\begin{array}{|lll|}3.7 & 16.3 & 4.9\end{array}$ & 1.5 & 747.9 & 11.0 \\
\hline Urban & $\begin{array}{lll}8.2 & 19.7 & 4.8 \\
\end{array}$ & $\begin{array}{lll}2.2 & 5.7 & 0.9\end{array}$ & 0.9 & 2.4 & 0.3 \\
\hline \multicolumn{6}{|l|}{ Capital } \\
\hline Total & $9.9 \quad 25.8 \quad 8.6$ & $\begin{array}{|lll|}2.4 & 7.7 & 1.9\end{array}$ & 0.9 & 3.3 & 0.7 \\
\hline Rural $(0-15,000)$ & $26.7 \quad 49.9 \quad 15.9$ & $\begin{array}{|lll|}7.5 & 17.2 & 3.2\end{array}$ & 3.0 & 7.8 & 1.2 \\
\hline Urban & $\begin{array}{lll}6.9 & 20.1 & 7.1 \\
\end{array}$ & \begin{tabular}{lll|}
1.5 & 5.5 & 1.6 \\
\end{tabular} & 0.5 & 2.3 & 0.6 \\
\hline \multicolumn{6}{|l|}{ Gulf } \\
\hline Total & $\begin{array}{lll}23.7 & 45.1 & 34.7\end{array}$ & \begin{tabular}{|lll}
7.8 & 17.9 & 11.0
\end{tabular} & 3.6 & 9.4 & 4.7 \\
\hline Rural $(0-15,000)$ & $\begin{array}{lll}30.5 & 52.6 & 43.7\end{array}$ & $10.2 \quad 21.8 \quad 15.2$ & 4.6 & 11.8 & 6.8 \\
\hline Urban & $\begin{array}{lll}14.3 & 34.7 & 24.2\end{array}$ & $\begin{array}{lll}4.5 & 12.6 & 6.2 \\
\end{array}$ & 2.1 & 6.0 & 2.3 \\
\hline \multicolumn{6}{|l|}{ Pacifico } \\
\hline Total & $\begin{array}{lll}12.6 & 26.7 & 13.7\end{array}$ & $\begin{array}{lll}4.4 & 8.4 & 3.6\end{array}$ & 2.2 & 4.0 & 1.7 \\
\hline Rural $(0-15,000)$ & $\begin{array}{lll}18.5 & 32.3 & 21.8\end{array}$ & $\begin{array}{lll}7.4 & 11.2 & 6.6\end{array}$ & 4.1 & 5.4 & 3.1 \\
\hline Urban & $\begin{array}{lll}8.5 & 23.0 & 9.4 \\
\end{array}$ & $\begin{array}{lll}2.2 & 6.7 & 2.1 \\
\end{array}$ & 0.9 & 3.2 & 1.0 \\
\hline \multicolumn{6}{|l|}{ South } \\
\hline Total & $\begin{array}{lll}41.1 & 60.0 & 39.9\end{array}$ & $\begin{array}{lll}15.3 & 26.6 & 14.3\end{array}$ & 7.3 & 14.8 & 7.0 \\
\hline Rural $(0-15,000)$ & $\begin{array}{lll}45.6 & 66.7 & 47.9\end{array}$ & $\begin{array}{lll}17.8 & 31.2 & 18.4\end{array}$ & 8.9 & 17.9 & 9.3 \\
\hline Urban & $\begin{array}{lll}30.9 & 45.7 & 24.4\end{array}$ & \begin{tabular}{|lll}
9.5 & 16.9 & 6.4 \\
\end{tabular} & 3.7 & 8.2 & 2.6 \\
\hline \multicolumn{6}{|l|}{ Center-North } \\
\hline Total & $\begin{array}{lll}28.5 & 44.5 & 21.1\end{array}$ & \begin{tabular}{|lll}
9.0 & 17.1 & 6.0
\end{tabular} & 4.2 & 8.8 & 2.7 \\
\hline Rural $(0-15,000)$ & $\begin{array}{lll}40.4 & 52.6 & 27.2\end{array}$ & $\begin{array}{lll}14.0 & 21.7 & 8.3\end{array}$ & 6.8 & 12.0 & 4.0 \\
\hline Urban & $\begin{array}{lll}18.2 & 36.7 & 16.4 \\
\end{array}$ & \begin{tabular}{|lll}
4.6 & 12.6 & 4.3 \\
\end{tabular} & 1.9 & 5.7 & 1.8 \\
\hline \multicolumn{6}{|l|}{ Center } \\
\hline Total & $\begin{array}{lll}44.7 & 49.5 & 30.1\end{array}$ & $\begin{array}{lll}16.1 & 20.0 & 10.3\end{array}$ & 7.9 & 17.3 & 5.0 \\
\hline Rural $(0-15,000)$ & $\begin{array}{llll}53.0 & 57.9 & 41.6\end{array}$ & $\begin{array}{lll}21.8 & 25.7 & 15.1\end{array}$ & 11.4 & 25.7 & 7.5 \\
\hline Urban & $\begin{array}{lll}34.5 & 37.0 & 15.4 \\
\end{array}$ & $\begin{array}{lll}9.1 & 11.4 & 4.1 \\
\end{array}$ & 3.6 & 4.9 & 1.8 \\
\hline
\end{tabular}

Source: ENIGH 1992-2002. Note: The ENIGH survey is not representative at the regional level. 


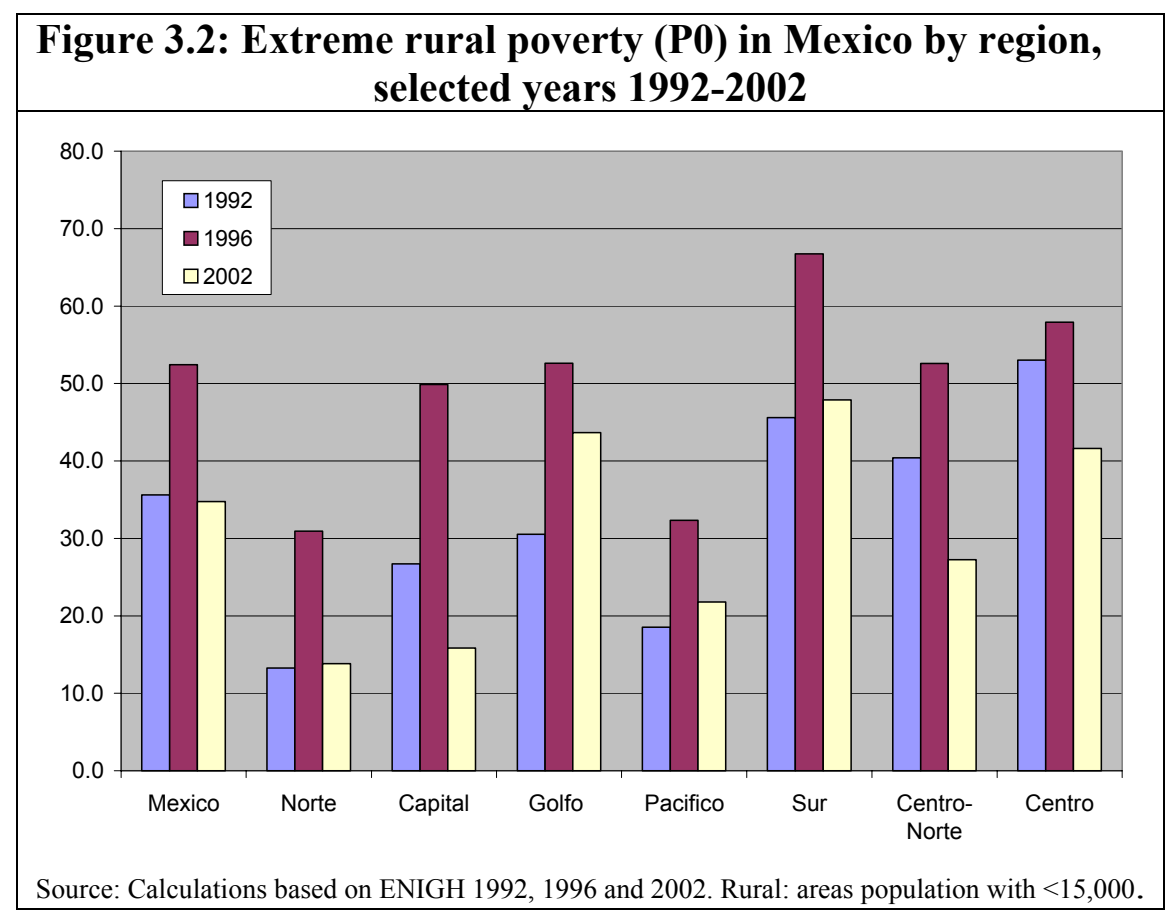

The distinction between regions seems to matter more for rural poverty than does that of rural and urban. As Figure 3.2 clearly shows, the Capital, Center, and CenterNorth regions experienced a considerable reduction in the headcount poverty rate over the past decade. The share of poor people in the total population fell by more than 10 percentage points in each region of these regions. This compares to the Gulf region where poverty increased by more than 10 percentage points during 1992-2002.

During 1992-2002, the pattern of overall poverty changes has closely followed the macroeconomic cycle and the associated rhythm of the labor market. The overall Mexican poverty was not stable, nor was rural poverty stable over the last decade. In rural areas P0 fell from 36 to 32 during 1992-94 and increased during the crises in 199596 where it hit an all-time high of 52 percent poverty rate. More populated rural areas (with between 2,500-15,000 inhabitants) have been more affected by the economic instability than dispersed rural areas (localities with less than 2,500 people). Poverty increased by 51 percent in the former and 27 percent in the latter areas during 1992-96. The crisis of 1994-95 constituted to a large setback for well-being in Mexico, and income poverty in 2002 is still close to levels prevailing a decade earlier, before the crisis. One result of the crises has been: (1) low labor returns in self-employment and wages independently of sector of engagement, and (2) increased under-employment for the poor.

Since 1996, the P0 embarked on a downward path and reaching in 2002 a level lower than at any point during the previous decade. While long run progress has been feeble, the measured trends in the 2000-02 period are encouraging, with a significant decline in extreme poverty, despite stagnation in average incomes driven by a 
combination of substantial income growth in rural areas, albeit with higher levels of rural inequality (World Bank 2004). During 1999-2002, the incomes of the poor population grew in Mexico, despite economy-wide stagnation (Appendix B). Two factors drove this, namely rapid growth in rural labor incomes of workers and self-employed, with some reduction in the wage premia to higher levels of education and large contribution from remittances and government transfers (Appendix B).

The income of the extreme poor households in rural areas is stagnant (Table 3.2). Average per-capita household income decreased from 1992-96 and increased during 1996-2002, but in 2002 it had still not return to the 1992 level. In 2002, the average income of the extreme poor rural households (P\$315.5) was less than a third of the average income of the non-poor in rural Mexico.

\begin{tabular}{|c|c|c|c|c|c|c|}
\hline \multicolumn{7}{|c|}{$\begin{array}{l}\text { Table 3.2: Average per-capita income by poverty level, } \\
\text { Mexico, selected years } 1992-2002\end{array}$} \\
\hline \multirow[b]{2}{*}{ Region } & \multicolumn{2}{|c|}{1992} & \multicolumn{2}{|c|}{1996} & \multicolumn{2}{|c|}{2002} \\
\hline & Non-poor & Poor & Non-poor & Poor & Non-poor & Poor \\
\hline Dispersed Rural ${ }^{1}$ & $1,277.76$ & 329.29 & $1,163.56$ & 302.80 & $1,417.20$ & 315.45 \\
\hline Semi-urban ${ }^{2}$ & $1,600.69$ & 346.55 & $1,304.62$ & 349.91 & $1,521.37$ & 327.74 \\
\hline Urban & $2,940.99$ & 520.70 & $2,470.30$ & 511.12 & $2,647.41$ & 506.64 \\
\hline
\end{tabular}

Rural household heads with no income decreased during 1992-2002 (Table 3.3). In 2002, 4.2 percent of household heads had no income, down 1.3 percentage points since 1992 and 0.8 percentage point since 1996. Two factors may have played a role in reducing the share of rural households with no incomes: first, increased education attainment in rural areas, and second, a reduction in the share of inactive households heads in rural areas. 


\begin{tabular}{|c|c|c|c|c|c|c|}
\hline \multicolumn{7}{|c|}{$\begin{array}{l}\text { Table 3.3: Household heads with no monetary income in rural Mexico, } \\
\text { Selected years 1992-2002 }\end{array}$} \\
\hline & \multicolumn{2}{|c|}{1992} & \multicolumn{2}{|c|}{1996} & \multicolumn{2}{|c|}{2002} \\
\hline & Urban & Rural & Urban & Rural & Urban & Rural \\
\hline Household heads with no income & & & & & & \\
\hline (a) Total Household Heads & $13,152,597$ & $4,183,553$ & $15,252,501$ & $4,667,367$ & $18,588,744$ & $5,595,519$ \\
\hline (b) No income heads & 694,848 & 229,130 & 866,784 & 232,449 & $1,059,990$ & 234,401 \\
\hline (b)/(a) & 5.28 & 5.48 & 5.68 & 4.98 & 5.70 & 4.19 \\
\hline Average Age & 61.39 & 61.91 & 60.09 & 61.77 & 61.61 & 64.05 \\
\hline Male & 51.87 & 68.72 & 58.09 & 64.12 & 46.07 & 71.69 \\
\hline Female & 48.13 & 31.28 & 41.91 & 35.88 & 53.93 & 28.31 \\
\hline Education & & & & & & \\
\hline No education & 30.05 & 67.29 & 29.35 & 55.37 & 25.01 & 50.00 \\
\hline Primary Incomplete & 36.18 & 28.91 & 32.59 & 32.02 & 34.18 & 34.07 \\
\hline Primary Complete & 21.22 & 2.93 & 23.52 & 11.28 & 23.52 & 13.52 \\
\hline Secondary Complete & 6.15 & 0.65 & 6.35 & 1.13 & 8.52 & 2.35 \\
\hline Higher Education & 6.40 & 0.21 & 8.18 & 0.21 & 8.77 & 0.06 \\
\hline Labor s & & & & & & \\
\hline Employed & 7.56 & 22.91 & 5.13 & 30.92 & 9.31 & 25.93 \\
\hline Unemployed & 7.88 & 1.30 & 15.24 & 4.63 & 5.83 & 3.64 \\
\hline Inactive & 84.56 & 75.79 & 79.63 & 64.45 & 84.86 & 70.42 \\
\hline
\end{tabular}

\subsection{Poverty Depth}

Although Mexico has made substantial progress since 1996 in reducing the share of the rural population living in extreme poverty, the problem remains broad and deep. The P0 measures the proportion of people below a certain poverty line but takes no account of how far they are below that line - the degree of poverty - or whether they are becoming even poorer. To address the situation of the poorest and to evaluate whether their economic situation has improved, the poverty gap (or P1) measure is used. In rural areas with less than 15,000 inhabitants the P1 poverty measure reveals that the extreme poverty depth fell 10 percentage points to 12 percent during 1996-2002 (Figure 3.3 and Table 3.1). However, the poverty gap measure reveals that poverty depth remained virtually unchanged in the 1992-2002 period.

The regional poverty gap figures reveal that there are also large regional differences in the depth of poverty in rural localities (Figure 3.4 and Table 3.1). In the North and Capital regions P1 was below 5 percent while in the Center, Gulf, and South P1 reached more than 15 percent in areas with less than 15,000 inhabitants in 2002. During 1992-1996 the poverty gap increased the most in the regions where poverty was less deep in 1992, such as the Capital and North regions where P1 reached 17 and 16 percent, respectively. The depth of poverty was at its highest for all the regions in the middle of the 1990s. 

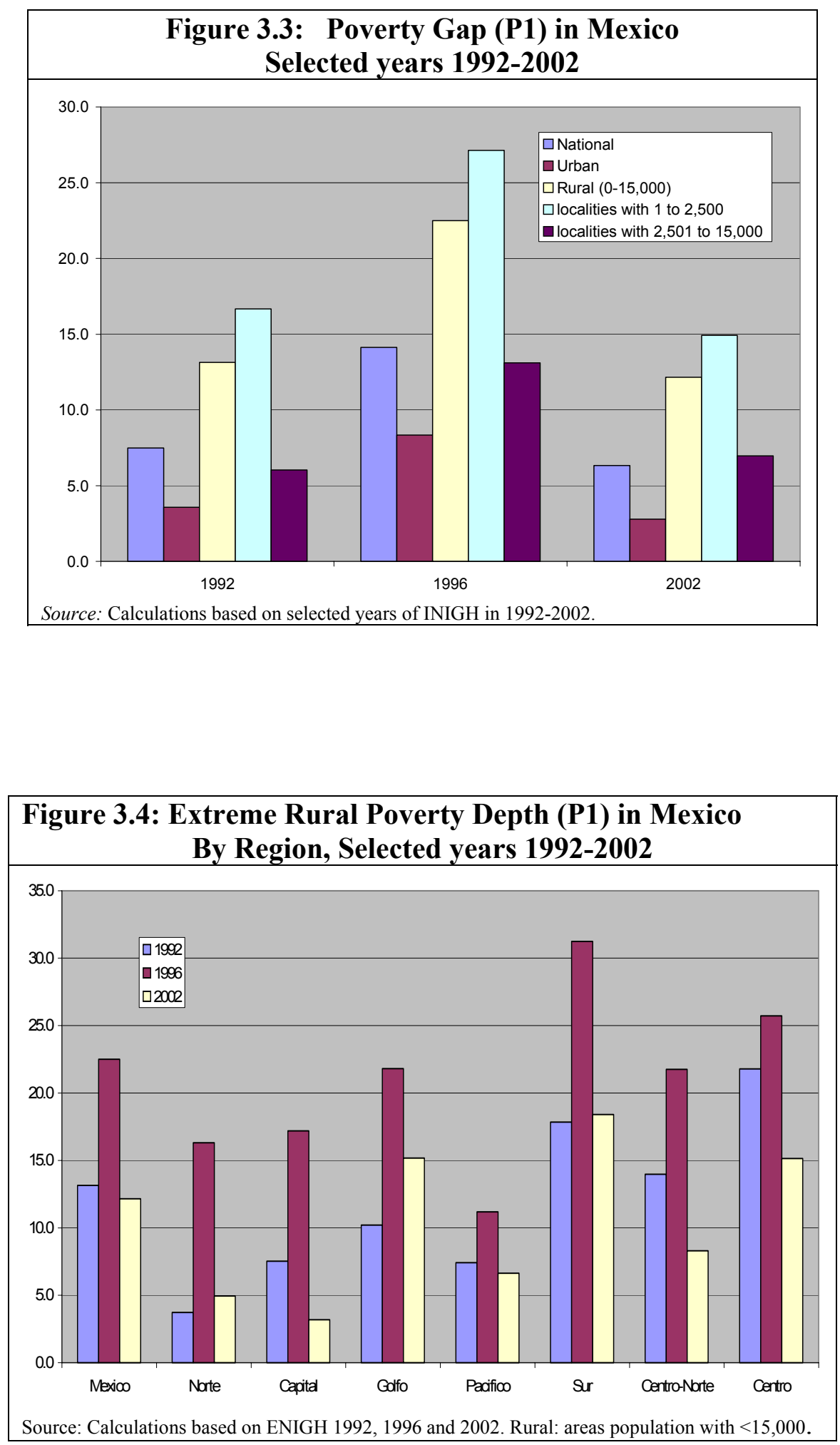


\subsection{Income Inequality}

Part of the reason why the poverty indicators of Mexico are worse than in other countries with similar per-capita incomes is because of income inequality. Mexico has an extremely unequal income distribution. Moreover, Mexico's income inequality has not changed much during the last decade and is stubbornly high. In 2002, the Gini coefficient for Mexico was above 0.51 , slightly higher than the coefficient for Mexico's rural areas of 0.48 (Figure 3.5). Moreover, the Gini coefficient reveals that rural income inequality has increased by 7 percentage points during 1992-2002. It is worth noting that international research shows that the more unequal income is distributed the less effective is economic growth in reducing poverty (Lustig et al 2001). Income poverty changes are driven by the interactions between growth and income inequality. In Mexico, even with steady growth, poverty reduction tends to be slow, as a consequence of the country's high-income inequality (World Bank 2004).

Changes in inequality are typically very slow, except during periods of radical social and institutional change. Where inequality has fallen it has usually happened in association with major expansion and equalization in educational attainment, as in Korea and Malaysia in the 1970s and 1980s. Mexico's expansion in education (reduction in education inequalities) may have been too recent to have a significant effect on the composition of skills, and occurred during a period in which the overall returns to high levels of skills were rising and returns to basic skills were falling.

In Mexico, inequality has tended to be counter cyclical with the 1994-95 crisis slightly equalizing, the 1996-2000 recovery disequalizing, and the 2000-02 period of stagnation equalizing for both income and expenditures, see Figure 4.5 from World Bank 2004. 


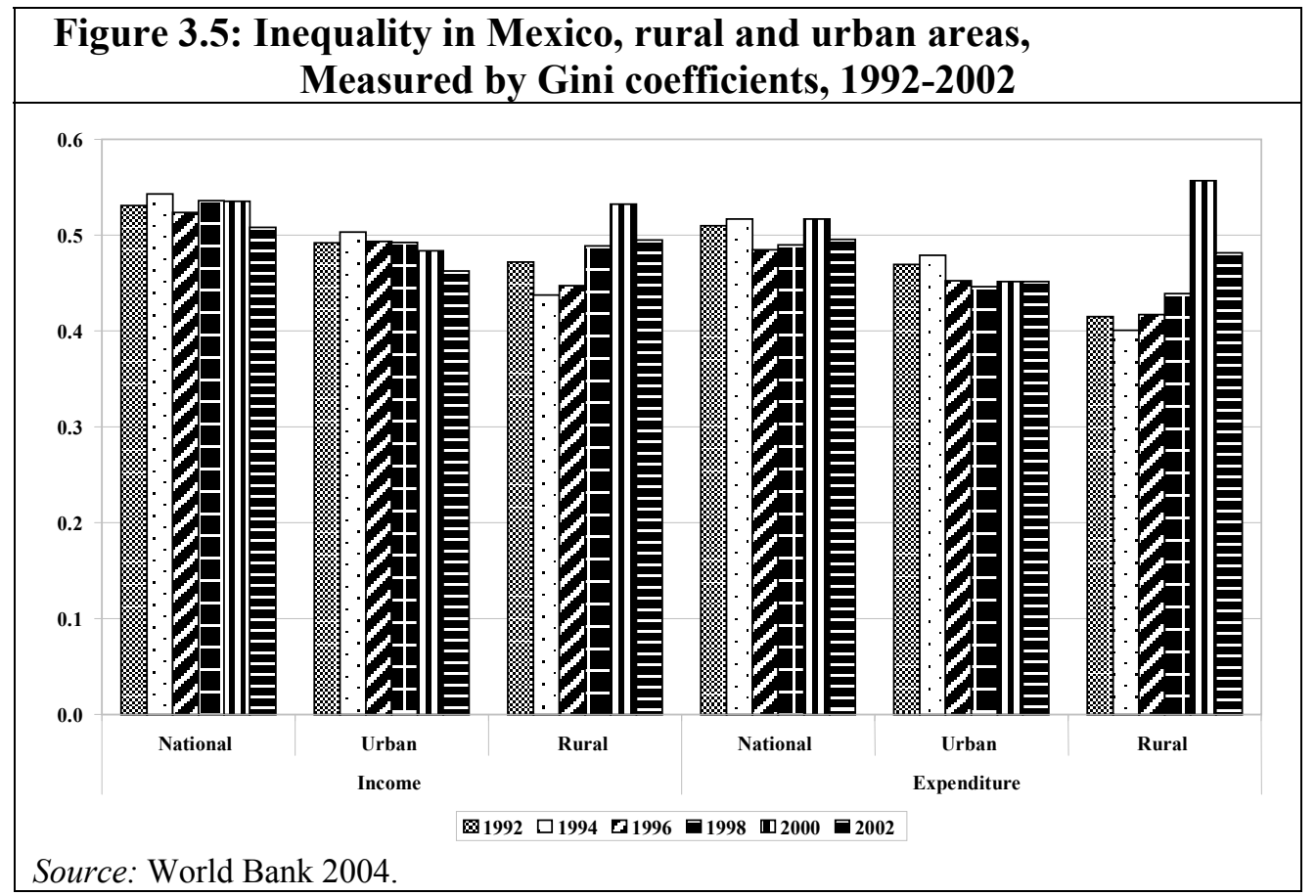

This contrasts the development of income inequality in urban areas that experienced an inequality reduction. The higher-productivity agriculture experienced rapid growth and so did high productivity non-farm income, which both contributed to increased rural inequality. Moreover, Mexico as a whole experienced a decrease in returns to tertiary education of workers in the labor market since around the middle of the 1990s and rural areas experience relatively little of this fall as very few of the rural population hold a university degree.

The poor have increased their access to government supplied services and infrastructure such as electricity, water and sanitation in the past decade. Ownership of household durables has also increased, but large inequalities remain in for example the ownership of housing and financial savings (World Bank 2004). Moreover, despite progress, there is evidence of Mexico lagging behind comparators in East Asian in infrastructure provision (World Bank 2004).

\section{Poverty Profile}

After counting the poor we need to know who they are, where they live, and what they do. Comparing average levels of poverty for different categories is useful for learning about which population groups are falling behind or catching up in terms of poverty. This is useful for the design of policies: we would like to know not only whether, for example, more- or less-educated people are more likely to be poor in rural Mexico, but how the relative odds of being poor have evolved for these groups. This section traces the evolution of the P0 for various population groups during 1992-2002. 
The poverty profile constructed is based on data from ENIGH. The main questions addressed are: (1) who are the poor, (2) what are the characteristics of poor households, (3) where do they live, and (4) where do they work. Table 4.1 presents the poverty profiles. 


\begin{tabular}{|c|c|c|c|c|c|c|c|c|c|c|c|c|c|c|c|c|c|c|}
\hline & \multirow{2}{*}{\multicolumn{9}{|c|}{1992}} & \multirow{2}{*}{\multicolumn{9}{|c|}{2002}} \\
\hline & & & & & & & & & & & & & & & & & & \\
\hline & \multicolumn{2}{|c|}{ Localities } & \multicolumn{7}{|c|}{ Region $^{3}$} & \multicolumn{2}{|c|}{ Localities } & \multicolumn{7}{|c|}{ Region $^{3}$} \\
\hline & \multirow[t]{2}{*}{ Rural $^{1}$} & \multirow{2}{*}{$\begin{array}{c}\text { Semi- } \\
\text { urban }^{2}\end{array}$} & \multicolumn{7}{|c|}{ Localities with less than 15,000} & \multirow[t]{2}{*}{ Rural $^{1}$} & \multirow{2}{*}{$\begin{array}{c}\text { Semi- } \\
\text { urban }^{2}\end{array}$} & \multicolumn{7}{|c|}{ Localities with less than 15,000} \\
\hline & & & Norte & Capital & Golfo & Pacifico & Sur & C-norte & Centro & & & Norte & Capital & Golfo I & Pacifico & Sur & C-norte & Centro \\
\hline Male & 38.2 & 14.9 & 10.8 & 20.0 & 28.38 & 16.0 & 40.49 & 33.41 & 46.9 & 36.84 & 16.95 & 0.76 & 10.03 & 40.75 & 19.50 & 41.56 & 23.32 & 35.81 \\
\hline Female & 36.6 & 4.0 & 9.0 & 25.64 & 25.9 & 10.7 & 25.05 & 28.83 & 32.3 & 32.11 & 11.65 & 0.24 & 11.31 & 30.19 & 8.40 & 23.19 & 22.08 & 31.79 \\
\hline \multicolumn{19}{|l|}{\begin{tabular}{|l|} 
Age Cohort (\%) \\
\end{tabular}} \\
\hline 15 to 25 & 27.4 & 16.3 & 6.4 & 20.00 & 28.28 & 21.89 & 26.83 & 22.73 & 34.0 & 30.49 & 6.25 & 1.59 & 2.37 & 43.05 & 17.51 & 33.22 & 13.81 & 40.42 \\
\hline 26 to 40 & 44.5 & 18.1 & 12.2 & 22.24 & 28.61 & 16.61 & 46.68 & 41.68 & 59.2 & 42.70 & 16.92 & 15.81 & 10.16 & 34.96 & 22.77 & 49.50 & 28.37 & 41.74 \\
\hline 41 to 60 & 37.7 & 10.3 & 10.4 & 22.54 & 28.71 & 13.95 & 38.13 & 36.78 & 35.7 & 36.00 & 15.43 & 10.45 & 12.30 & 39.63 & 17.83 & 38.12 & 18.06 & 33.41 \\
\hline$>61$ & 31.4 & 8.2 & 9.7 & 12.50 & 25.47 & 11.53 & 28.98 & 19.56 & 41.9 & 30.05 & 15.43 & 16.61 & 8.97 & 44.33 & 10.28 & 26.36 & 25.56 & 28.05 \\
\hline \multicolumn{19}{|l|}{ Education (\%) } \\
\hline No education & 46.2 & 25.2 & 14.8 & 39.78 & 29.01 & 17.84 & 52.76 & 36.98 & 65.4 & 44.98 & 28.09 & 25.91 & 14.48 & 54.66 & 21.52 & 44.03 & 32.32 & 46.25 \\
\hline Primary incomplete & 38.0 & 11.4 & 10.6 & 21.55 & 25.22 & 13.71 & 38.32 & 37.84 & 43.6 & 36.18 & 21.10 & 14.07 & 17.81 & 42.35 & 30.66 & 41.43 & 23.04 & 34.37 \\
\hline Primary complete & 31.0 & 15.0 & 7.4 & 23.86 & 43.08 & 23.92 & 22.54 & 23.55 & 25.2 & 36.09 & 13.73 & 12.02 & 3.58 & 42.39 & 13.38 & 36.43 & 24.51 & 34.56 \\
\hline Secondary complete & 22.0 & 7.0 & 11.5 & 3.08 & 6.78 & 11.33 & 22.66 & 19.90 & 19.8 & 17.93 & 8.91 & 2.52 & 7.25 & 14.61 & 9.43 & 24.71 & 12.31 & 20.23 \\
\hline Higher education & 0.7 & 0.4 & - & - & - & 0.58 & - & - & 4.8 & 12.46 & 0.65 & 4.57 & 2.89 & 5.35 & 2.31 & 7.90 & 0.17 & 5.26 \\
\hline \multicolumn{19}{|l|}{ Labor Status (\%) } \\
\hline Employed & 38.5 & 14.2 & 10.4 & 19.37 & 29.06 & 15.60 & 39.96 & 33.02 & 45.2 & 37.11 & 16.53 & 12.71 & 10.95 & 40.47 & 18.49 & 39.30 & 22.65 & 36.02 \\
\hline Unemployed & 56.6 & 39.5 & 23.6 & - & 56.29 & 55.78 & 100.00 & 37.80 & 83.1 & 20.38 & 18.78 & 4.41 & 16.98 & 18.94 & 31.44 & 97.17 & 10.97 & - \\
\hline Inactive & 32.7 & 6.4 & 11.0 & 37.30 & 14.84 & 11.55 & 21.06 & 33.67 & 45.4 & 29.43 & 11.96 & 13.96 & 4.57 & 26.56 & 12.72 & 25.87 & 25.23 & 28.37 \\
\hline \multicolumn{19}{|l|}{ Work Position (\%) } \\
\hline Salaried worker & 39.3 & 13.7 & 10.5 & 22.27 & 29.92 & 15.00 & 33.32 & 39.70 & 50.98 & 35.27 & 14.27 & 11.50 & 6.98 & 37.21 & 16.05 & 39.58 & 24.79 & 36.56 \\
\hline Self-employed & 42.6 & 14.5 & 13.5 & 14.41 & 32.07 & 18.74 & 46.73 & 29.10 & 38.86 & 42.21 & 20.59 & 16.86 & 19.59 & 49.87 & 23.90 & 40.96 & 23.88 & 37.40 \\
\hline Employer & 21.3 & 16.6 & 0.6 & - & 19.29 & 7.36 & 30.13 & 12.01 & 35.53 & 17.02 & 12.32 & 2.31 & 9.53 & 19.18 & 7.63 & 23.99 & 7.73 & 19.63 \\
\hline Family worker & 36.3 & & 30.2 & - & - & 88.34 & - & 100.00 & 63.57 & 39.28 & - & 0.93 & 39.98 & - & 32.75 & 34.38 & 23.53 & 75.89 \\
\hline \multicolumn{19}{|l|}{ Work Sector (\%) } \\
\hline Agropecuarian & 43.7 & 21.3 & 14.5 & 29.68 & 40.26 & 29.77 & 46.03 & 35.89 & 51.12 & 45.28 & 36.00 & 13.89 & 23.19 & 58.11 & 29.40 & 50.29 & 28.44 & 49.87 \\
\hline Extraction & 26.2 & 9.8 & - & - & 39.66 & 56.17 & - & 26.92 & - & 7.67 & 1.11 & - & - & 9.48 & - & 100.00 & 1.68 & - \\
\hline Manufacturing & 24.3 & 6.4 & - & 4.17 & 9.74 & 1.78 & 41.76 & 33.31 & 34.65 & 22.09 & 7.51 & 2.34 & 14.63 & 21.12 & 16.88 & 12.81 & 7.47 & 14.98 \\
\hline Construction & 40.3 & 16.5 & 3.2 & 26.3 & 39.35 & 3.36 & 18.07 & 42.20 & 60.73 & 35.80 & 21.58 & 12.68 & 10.42 & 40.70 & 34.74 & 45.59 & 27.17 & 42.39 \\
\hline Utilities & 7.7 & & - & - & 23.86 & 19.21 & - & - & - & - & 24.32 & - & 4.11 & - & - & - & - & 100.00 \\
\hline Sales & 25.5 & 12.0 & 7.7 & 26.5 & 25.50 & 8.53 & 22.81 & 15.98 & 27.44 & 23.18 & 6.97 & 4.26 & 2.28 & 26.44 & 6.61 & 17.11 & 21.53 & 23.67 \\
\hline Hotel-restaurant & 1.9 & 0.2 & - & - & 4.85 & - & 0.45 & - & - & 15.38 & 6.64 & 14.22 & - & 15.59 & 9.57 & 0.57 & - & 18.46 \\
\hline Services & 23.6 & 14.6 & 8.2 & 18.6 & 13.37 & 3.65 & 28.30 & 24.26 & 22.75 & 23.06 & 14.08 & 24.29 & 3.52 & 22.77 & 5.40 & 33.04 & 16.72 & 19.75 \\
\hline Education & 1.4 & 0.9 & - & - & - & - & - & 2.61 & 6.19 & 1.83 & 1.13 & 7.60 & - & 4.06 & - & - & - & - \\
\hline Government & 23.6 & 0.1 & - & 12.2 & 16.34 & 0.93 & 24.56 & 19.21 & 2.10 & 25.11 & 2.28 & 14.15 & 0.40 & 22.90 & - & 15.55 & 24.79 & 18.62 \\
\hline
\end{tabular}


Education levels are strongly related to poverty. That is, having incomplete or some complete education is important in determining the likelihood of being poor. In Mexico, the P0 is 45 percent for household heads that have received no education in dispersed rural areas and 28 percent in semi-urban areas in 2002.

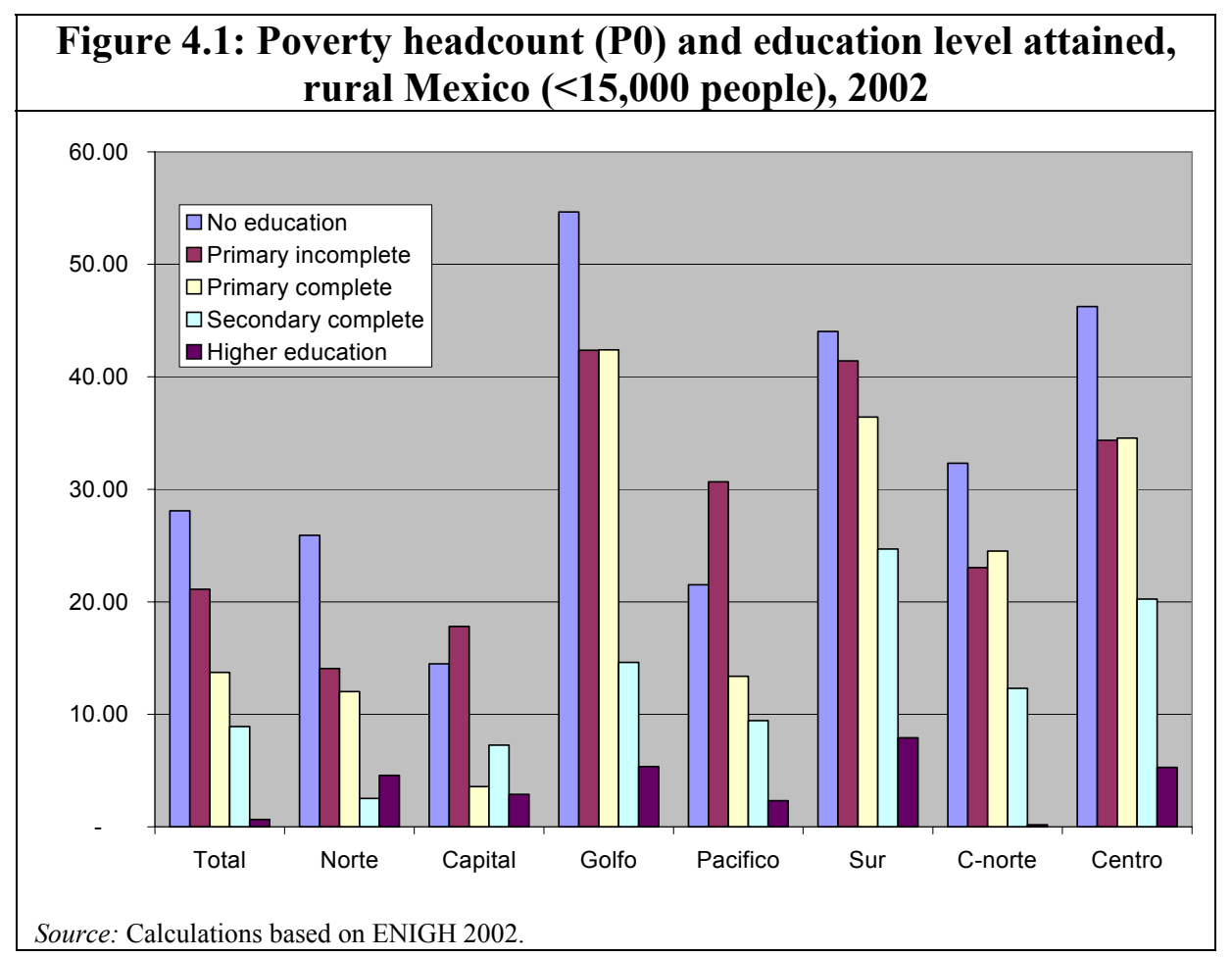

There appears to be a relatively large difference in extreme poverty between household heads with no education (45 percent) and household heads with incomplete primary education (36 percent) in dispersed rural areas. Surprisingly, there seems to be very little difference in extreme poverty between household heads with incomplete primary education and household heads with complete primary education (36 percent), the latter up from 31 percent in 1992. Nevertheless, household heads that have completed secondary education are much better off (18 percent are poor) than those with only primary education. Extreme poverty for high-school graduates decreased rapidly during 1992-2002, down from 22 percent in 1992. Of the household heads with some or complete tertiary education 13 percent were extremely poor in 2002, up from 1 percent in 1992. These findings indicate that education is a very important key to poverty reduction in rural Mexico. It is not a silver bullet, however, as the more educated are increasingly experiencing poverty, something that was rare a decade ago.It is useful to compare the characteristics of the extreme poor across rural areas to gain information about the spatial dimension of poverty. Geographic factors are important when analyzing poverty in rural Mexico. Table 4.1 and Figure 4.1 show the variation in P0 across the rural areas with less than 15,000 inhabitants by region and education level attained. The Center, Gulf, and South regions have the highest headcount poverty rates for all levels of education in rural Mexico and, in some cases, it is more than 10 times higher than in the North or Capital regions such as the case of completed primary 
education. Also, the headcount poverty rates for household heads with no- or little education are all higher in rural and semi-urban areas than in urban areas. For high school graduates, rural heads of household have a lower P0 than urban heads of household (18 percent).

In rural areas with less than 15,000 inhabitants, the gap in P0 between the educated and less educated is widening: the more educated are experiencing a slightly higher headcount poverty rate, while the less educated (with no or incomplete primary education) are getting left behind. Figure 4.1 shows that there are very large differences in poverty levels by education, and that they have increased over time: since 1992, the P0 for people with none or/and incomplete primary education appears to have increased a lot--the later by 10 percentage points reaching 21 percent in 2002--while the P0 for people with complete secondary and some university education stabilized or increased only marginally from its already very low level. In Mexico, as elsewhere, there is a great deal of debate about the causes of these changes: skill-biased technological change, changes in the relative supply of and demand for workers with different characteristics, and trade liberalization have all been mentioned as possible explanations (Blom and Velez 2001; Blom, Pavcnik, and Schady 2001).

Young household heads in semi-urban areas are far less likely to be poor than in dispersed rural areas. Data reveal that 6 percent of the households headed by a person younger than age 25 are extremely poor in semi-urban areas. Moreover, the poverty rate for these households fell 10 percentage points during 1992-2002, down to nearly a third in the last decade. In rural areas with less than 2,500 people 31 percent of the households headed by a person younger than age 25 are extremely poor. Furthermore, poverty is rising, P0 increased by 4 percentage points since 1992 in dispersed rural areas. Targeted social protection measures that relate to youth employment, family planning, and pre-school programs could help improve employment prospects of young people in dispersed rural areas.

Elder household heads used to be less likely to experience poverty than younger household heads in rural Mexico. Fifteen percent of those households headed by a member older than age 60 were below the indigent poverty line in 2002-a 7-percentage- points increase since 1992. In the more dispersed rural areas poverty for this group has stabilized at around 30 percent during 1992-2002. The P0 of population groups aged 25 to 40 and 41 to 60 were stable at around 43 and 37 percent over the decade in dispersed rural areas, but in semiurban rural areas experienced an increase in poverty for the latter group. This life-cycle profile of poverty illustrates that many households are born poor (mainly due to inadequate assets), with few households escaping poverty as they accumulate more assets or as their household size shrinks but faces increased risk of returning to poverty at an old age.

Female-headed households are less likely to be poor than male-headed households in semi-urban rural areas, with 12 and 17 percent of female- and male-headed households, respectively, likely to be poor (Table 4.1). Since 1992, female-headed households have experienced poverty rates triple and male-headed households have experienced only a marginal increase ( 2 percentage points). This compares to more dispersed rural areas where male poverty stabilized around 37 percent during 1992-2002 and female poverty rates fell 4 percentage points reaching 32 percent in 2002 . These income poverty figures are, however, 
only part of the myriad of factors that affect a poor woman's well being. Data do not reveal anything about domestic violence and other types of discrimination that women often face.

Those who work in agriculture are far more likely to be poor than others. This may suggest that productivity in agriculture is lower than in services or industry. The P0 is 36 and 45 percent in agriculture in semi-urban and dispersed rural areas. This compares to P0 in manufacturing of 8 and 22 percent and 14 and 23 percent among service workers (excluding sales and hotel/restaurants that is much lower) in semi-urban and more dispersed rural areas, respectively in 2002. Moreover, the agricultural workers' poverty rate increased by an astounding 15 percentage points in the last decade in semi-urban areas as compared to 1 percentage point increase in industry and 0 percentage points in services. This development pattern is different to the one in dispersed rural areas in the same period. In dispersed rural areas heads of household working in agriculture experienced poverty increase by only 1 percentage point, in industry the poverty rate fell by 2 percentage points, and in services it remained unchanged.

Sectoral poverty by region and the changes that occurred over the past decade were far from homogeneous across semi-urban and rural Mexico. In the Golf and South regions 58 and 50 percent of the households headed by a person working in agriculture were extremely poor in 2002, up 12 and 4 percentage points, respectively since 1992 (Table 4.1). This compares to the North region where 15 percent of the households headed by a person working in agriculture were extremely poor. Poverty in households where the head works in construction experienced a high likelihood of poverty in the South region and much less so in the Capital region, 46 and 18 percent, respectively were poor in 2002, up from 18 percent and down from 18 percent, respectively.

Historically, poverty in Mexico has been closely associated with agriculture. In 2002, 72 percent of the extreme poor household heads in dispersed rural areas cited agriculture as their primary form of employment. The main explanation for the increased poverty rate in agriculture can be traced to migration out of the sector and into services by some of the most skilled and, in part, to the structure of land ownership and the quality of land and climate. Rural land ownership is characterized by a high degree of concentration of land in few large establishments and a large number of small farms with an insufficient area to sustain a family by agricultural employment alone.

In dispersed rural areas the most skilled agricultural workers shifted employment out of agriculture toward higher wage service jobs. In 2002, 7 percent of the poor worked in services and 10 percent in construction.

Rural poverty fell in recent years but it is still much larger than urban poverty. Onequarter of Mexico's population lives in rural areas, with limited access to basic infrastructure and services. The rural poor are primarily smallholders, sharecroppers, and informal wageworkers that depend on a diverse strategy of income-generating activities in which the subsistence production of corn, beans, sorghum, and small livestock predominates. Often rainfall is scarce and highly irregular, yielding crops of low quality and low income generating capacity. These small farmers lack modern production technology, basic infrastructure to store harvests to take advantage of cyclical price fluctuations, technical 
assistance to improve productivity, and organized marketing facilities. Family income is therefore highly variable and there is little opportunity for saving. They have very few assets, including education, and are very vulnerable.

The differing characteristics of the smallholders, sharecroppers, and wageworkers suggest that a poverty reduction strategy needs to provide multiple paths out of poverty tailored to the heterogeneous cross-section of poor rural households. This will involve at least a five-pronged approach aimed at: (i) small farm sector intensification, (ii) improved employment opportunities in dynamic commercial agriculture, (iii) growth of the rural nonfarm sector, (iv) migration of the young, and (v) provision of safety nets for those "trapped" in poverty. The recommended measures include improving human capital endowments, reforming the land, labor, and financial markets, enhancing research and extension, improving the supply of public goods and services, pricing and trade policies, and transfer programs.

In order to increase land productivity and labor-intensive farming, it is necessary to facilitate the movement toward farming medium-sized land holdings, in part via facilitating land rentals and sharecropping arrangements. This can be done by providing more secure titles to land and by the revision of the land legislation so as to secure longer-term tenancy arrangements, resolution of disputes regarding interpretation, and enforcement of land rental arrangements. The impact of such a program would be greatly enhanced by simultaneous adjustments of the labor code and of the land tax system. Labor laws have had an antisharecropping bias. In this context, the experience with the Rural Leasing Exchange in the Triângulo Mineiro in Brazil contains useful lessons that could be worth considering for Mexico.

Extreme rural poverty is not distributed equally across population groups. The incidence of poverty is much larger among indigenous peoples that are at the bottom of the income distribution. ${ }^{6}$ According to 2000 Census, 44 percent of indigenous groups are in the bottom 20 percent of the overall distribution of income, and 80 percent in the bottom 50 percent (Hall et al 2004). Hence, indigenous peoples account for about a fifth of the extreme poor that is, over twice their population share. Moreover, indigenous groups typically suffer higher levels of deprivation in terms of access to public services.

\footnotetext{
${ }^{6}$ The ENIGH does not include a question on ethnicity.
} 


\section{Poverty Correlates}

After analyzing the poverty profile, this section turns to the factors associated with poverty in rural Mexico (areas with less than 15,000 inhabitants). Many individual characteristics such as labor market association and human capital are important correlates of poverty and the dynamics thereof. This section investigates the marginal impact of each individual attribute on the likelihood that a household falls below the poverty line. The analysis is undertaken applying probit regression techniques.

Other researchers have addressed the determinates of poverty, for example, Ferreira, Lanjouw and Neri (1999) for Brazil, and these authors perform the study for one year, which gives a good but static picture of the situation in a country. Here the analysis is more dynamic in nature as it is based on three ENIGH data from the years 1992, 1996, and 2002. This allows for an evaluation of the evolution of poverty over time and the most important variables determining poverty. Hence, three poverty analyses are performed for rural Mexico as a whole using data from localities with less than 15,000 inhabitants. This analysis reveals: (i) conditional correlation between poverty and characteristics of household heads; (ii) information about the volatility of the impact of the attributes on the likelihood that a household experiences poverty during the beginning and mid-1990s and beginning of the 2000s; and (iii) information about groups that are particularly vulnerable and changes thereof over the past decade.

The status of the household - poor or nonpoor-is regressed on relevant individual and household characteristics. The dependent variable takes the value of 1 if the average percapita income is below the SEDESOL capacity poverty line and 0 otherwise. The dependent binary variable takes the value of one when income is below the indigence line and zero otherwise. The vector of five sets of independent variables includes: (1) attributes of household head: gender, education, experience and labor market connection, whether the household head works, the type of relation with the labor market, sector of employment; (2) family variables: size and age of its members; (3) spouse characteristics: education and labor market connection; (4) geographical characteristics; and (5) dispersed rural areas.

Probit coefficients are not easy to interpret, since they do not represent the standard marginal effects represented by linear regression coefficients. Therefore, rather than probit coefficients we chose to present marginal effects that have a straightforward interpretation. ${ }^{7}$

\footnotetext{
${ }^{7}$ The marginal effects for a household head $i$ in the Probit model are simply given by:

$$
m_{i}=\frac{d \operatorname{Pr}\left(y_{i}=1\right)}{d x_{i}}=\phi\left(x_{i} \beta\right) \beta
$$

This represents the marginal changes in probability that a household head $i$ is poor due to changes in the underlying regressors. In order to summarize representative marginal effects, the changes are evaluated at the mean of the data. Since similar conditions apply for marginal effects as for probit coefficients, the same tests for the positively, negativity or significance can be applied.
} 
Table 5.1: Probability of being poor in Rural Mexico in 1992, 1996, and 2002 ${ }^{1,2}$

\begin{tabular}{|c|c|c|c|c|c|c|c|c|c|c|c|c|}
\hline & \multicolumn{4}{|c|}{1992} & \multicolumn{4}{|c|}{1996} & \multicolumn{4}{|c|}{2002} \\
\hline & DF/dx & & SE & $\mathbf{P}>|\mathbf{z}|$ & $d F / d x$ & & SE & $\mathbf{P}>|\mathbf{z}|$ & $d F / d x$ & & SE & $\mathbf{P}>|\mathbf{z}|$ \\
\hline \multicolumn{13}{|l|}{ Household Characteristics $^{3}$} \\
\hline Dependent below 5 years old + & 0.215 & $* * *$ & 0.017 & 0.000 & 0.234 & $* * *$ & 0.016 & 0.000 & 0.225 & $* * *$ & 0.016 & 0.000 \\
\hline Dependent $6-11$ years old + & 0.174 & $* * *$ & 0.017 & 0.000 & 0.250 & $* * *$ & 0.015 & 0.000 & 0.218 & $* * *$ & 0.015 & 0.000 \\
\hline Dependent 12 - 14 years old + & 0.114 & $* * *$ & 0.019 & 0.000 & 0.119 & $* * *$ & 0.017 & 0.000 & 0.135 & $* * *$ & 0.017 & 0.000 \\
\hline Dependent 15 - 18 years old + & 0.026 & & 0.019 & 0.177 & 0.053 & $* * *$ & 0.018 & 0.003 & 0.057 & $* * *$ & 0.017 & 0.001 \\
\hline Dependent 18 - 25 years old + & -0.069 & $* * *$ & 0.019 & 0.000 & -0.046 & $* *$ & 0.018 & 0.012 & -0.059 & $* * *$ & 0.017 & 0.001 \\
\hline Dependent 65 and over+ & 0.047 & $* *$ & 0.020 & 0.018 & 0.051 & $* * *$ & 0.019 & 0.007 & 0.003 & & 0.017 & 0.839 \\
\hline Head & & & & & & & & & & & & \\
\hline Age + & -0.008 & $* * *$ & 0.003 & 0.009 & -0.016 & $* * *$ & 0.003 & 0.000 & -0.021 & $* * *$ & 0.003 & 0.000 \\
\hline Age Square + & 0.000 & $* *$ & 0.000 & 0.031 & 0.000 & $* * *$ & 0.000 & 0.000 & 0.000 & $* * *$ & 0.000 & 0.000 \\
\hline Female Head + & -0.030 & & 0.028 & 0.295 & -0.089 & $* * *$ & 0.024 & 0.000 & -0.037 & $*$ & 0.021 & 0.087 \\
\hline \multicolumn{13}{|l|}{\begin{tabular}{|l|} 
Education \\
\end{tabular}} \\
\hline Head & & & & & & & & & & & & \\
\hline Primary Complete+ & -0.102 & $* * *$ & 0.020 & 0.000 & -0.082 & $* * *$ & 0.020 & 0.000 & -0.097 & $* * *$ & 0.016 & 0.000 \\
\hline Lower Secondary Complete+ & -0.167 & $* * *$ & 0.027 & 0.000 & -0.232 & $* * *$ & 0.027 & 0.000 & -0.180 & $* * *$ & 0.022 & 0.000 \\
\hline Upper Secondary Complete+ & -0.210 & $* * *$ & 0.042 & 0.000 & -0.343 & $* * *$ & 0.033 & 0.000 & -0.239 & $* * *$ & 0.029 & 0.000 \\
\hline Spouse & & & & & & & & & & & & \\
\hline Primary Complete+ & -0.075 & $* * *$ & 0.021 & 0.001 & -0.069 & $* * *$ & 0.021 & 0.001 & -0.095 & $* * *$ & 0.018 & 0.000 \\
\hline Lower Secondary Complete+ & -0.116 & $* * *$ & 0.034 & 0.002 & -0.182 & $* * *$ & 0.031 & 0.000 & -0.171 & $* * *$ & 0.024 & 0.000 \\
\hline Upper Secondary Complete + & -0.213 & $* * *$ & 0.051 & 0.003 & -0.364 & $* * *$ & 0.046 & 0.000 & -0.273 & $* * *$ & 0.032 & 0.000 \\
\hline \multicolumn{13}{|c|}{ Sector of Activity and Labor Status } \\
\hline Head & & & & & & & & & & & & \\
\hline Unemployed + & 0.083 & & 0.095 & 0.365 & 0.205 & $* * *$ & 0.063 & 0.004 & 0.074 & & 0.092 & 0.414 \\
\hline $\begin{array}{l}\text { Not in the labor force }+ \\
\text { Agriculture }\end{array}$ & 0.060 & & 0.038 & 0.103 & 0.050 & & 0.032 & 0.128 & 0.105 & $* * *$ & 0.030 & 0.000 \\
\hline Self employed + & 0.006 & & 0.025 & 0.808 & 0.031 & & 0.025 & 0.213 & 0.219 & $* * *$ & 0.024 & 0.000 \\
\hline Salaried worker+ & 0.166 & $* * *$ & 0.026 & 0.000 & 0.155 & $* * *$ & 0.023 & 0.000 & 0.216 & $* * *$ & 0.023 & 0.000 \\
\hline Employer+ $\quad$ Off-farm Sector & -0.156 & $* * *$ & 0.026 & 0.000 & -0.185 & $* * *$ & 0.033 & 0.000 & -0.054 & & 0.041 & 0.199 \\
\hline $\begin{array}{l}\text { Self employed }+ \\
\text { Salaried worker }+\end{array}$ & -0.040 & & 0.030 & 0.195 & -0.044 & & 0.029 & 0.126 & 0.046 & * & 0.027 & 0.083 \\
\hline Employer+ & -0.255 & $* * *$ & 0.034 & 0.000 & -0.356 & $* * *$ & 0.039 & 0.000 & -0.141 & $* *$ & 0.051 & 0.015 \\
\hline Second Employment + & 0.010 & & 0.017 & 0.550 & -0.031 & $*$ & 0.017 & 0.070 & -0.061 & $* * *$ & 0.016 & 0.000 \\
\hline Social Security + Spouse & -0.206 & $* * *$ & 0.020 & 0.000 & -0.251 & $* * *$ & 0.024 & 0.000 & -0.235 & $* * *$ & 0.019 & 0.000 \\
\hline Employed in agriculture + & -0.017 & & 0.031 & 0.595 & -0.019 & & 0.027 & 0.487 & 0.065 & $* * *$ & 0.026 & 0.010 \\
\hline Employed in off-farm activity + & -0.067 & $* * *$ & 0.023 & 0.005 & -0.123 & $* * *$ & 0.021 & 0.000 & -0.133 & $* * *$ & 0.017 & 0.000 \\
\hline \multicolumn{13}{|l|}{ Region $^{4}$} \\
\hline Norte + & -0.166 & $* * *$ & 0.022 & 0.000 & -0.155 & $* * *$ & 0.026 & 0.000 & -0.051 & $* *$ & 0.024 & 0.041 \\
\hline Golfo Region+ & 0.061 & $* *$ & 0.026 & 0.017 & 0.117 & $* * *$ & 0.023 & 0.000 & 0.222 & $* * *$ & 0.024 & 0.000 \\
\hline Pacifico+ + & -0.145 & $* * *$ & 0.022 & 0.000 & -0.152 & $* * *$ & 0.025 & 0.000 & -0.010 & & 0.025 & 0.696 \\
\hline Sur+ & 0.134 & $* * *$ & 0.029 & 0.000 & 0.161 & $* * *$ & 0.024 & 0.000 & 0.190 & $* * *$ & 0.023 & 0.000 \\
\hline Centro+ & 0.037 & & 0.024 & 0.113 & 0.096 & $* * *$ & 0.025 & 0.000 & 0.155 & $* * *$ & 0.025 & 0.000 \\
\hline Capital+ & -0.113 & $* * *$ & 0.038 & 0.008 & 0.014 & & 0.050 & 0.778 & -0.086 & $* * *$ & 0.029 & 0.005 \\
\hline Locality $<2,500$ inhabitants + & 0.085 & $* * *$ & 0.020 & 0.000 & 0.132 & $* * *$ & 0.017 & 0.000 & 0.120 & $* * *$ & 0.015 & 0.000 \\
\hline Number of observations $=$ & 4752 & & & & 6165 & & & & & & & 6481 \\
\hline Log Likelihood= & -2442.4 & & & & -3176.2 & & & & & & & -3145.7 \\
\hline$L R \operatorname{chi} 2(24)=$ & 1360.4 & & & & 2180.1 & & & & & & & 2448.7 \\
\hline Prob $>$ chi2 $=$ & 0.000 & & & & 0.000 & & & & & & & 0.000 \\
\hline Pseudo R2= & 0.218 & & & & 0.256 & & & & & & & 0.280 \\
\hline
\end{tabular}


The poverty profile probit regressions can be interpreted as descriptive and do not infer anything in terms of causation. In the following, mainly statistically significant differences are discussed. Table 5.1 presents three probit models for rural Mexico linking the probability of being poor to a range of explanatory variables for 1992, 1996 and 2002.

Findings presented in Table 5.1 show that the major changes during 1992-96 in the rural poverty correlates relate to human capital (secondary education and skills in particular). Household heads and spouses with a relatively high level of human capital, that is, completed lower or upper secondary school experienced a reduced probability of falling into poverty compared to 1992, controlling for other variables. Also, employers experienced a fall in likelihood of experiencing poverty during 1992-96. Households in which the head had employment and with children age 6-11 and 15-18 experienced an increase in the likelihood of being poor relative to their peers in households with an employed head and with no children. Finally, the dispersed rural population experienced an increase the probability of being poor.

Also during 1996-2002 major changes took place. One such change was that female household heads became less poverty prone than male heads, taking into account other poverty correlates. The self-employed and salaried workers in the agricultural sector experienced an increased probability of falling into poverty than their peers in the non-farm sector. The educated households mentioned above experienced an increased likelihood of being poor, returning roughly to the 1992 level.

\section{Rural living}

Households living in semi-urban areas were more likely to escape poverty than households living dispersed rural areas. In 2002, household heads living in dispersed rural areas were around 12 percentage points more likely to be poor than household heads living in semi-urban areas (Table 5.1). Moreover, the probability of falling below the poverty line for household heads in dispersed rural areas increased by 3.5 percentage points during 19922002. Furthermore, the rural population in dispersed areas in the South region was more likely to experience poverty than in dispersed rural areas in Mexico as a whole in 1992 (Table 5.2). Interestingly, dwellers in dispersed rural areas in the South region were also more likely to be poor than dwellers in more populated rural areas in 2002, but the impact is much lower than for rural population in dispersed areas in Mexico as a whole.

\section{Labor Status and Sector of Work}

The informal sector is a pervasive and persistent economic feature of most developing economies, contributing significantly to employment creation, production, and income generation. The analysis presented in Table 5.1 shows clearly that formal sector workers, i.e. workers contributing to the social security system, are much less likely to be poor than informal sector workers in rural Mexico. The likelihood of escaping poverty for the formal sector workers increased during 1992-96 and seems to have been fairly constant since. In 2002, formal sector workers were 24 percentage points less likely to fall into poverty than their peers working in the informal sector. 


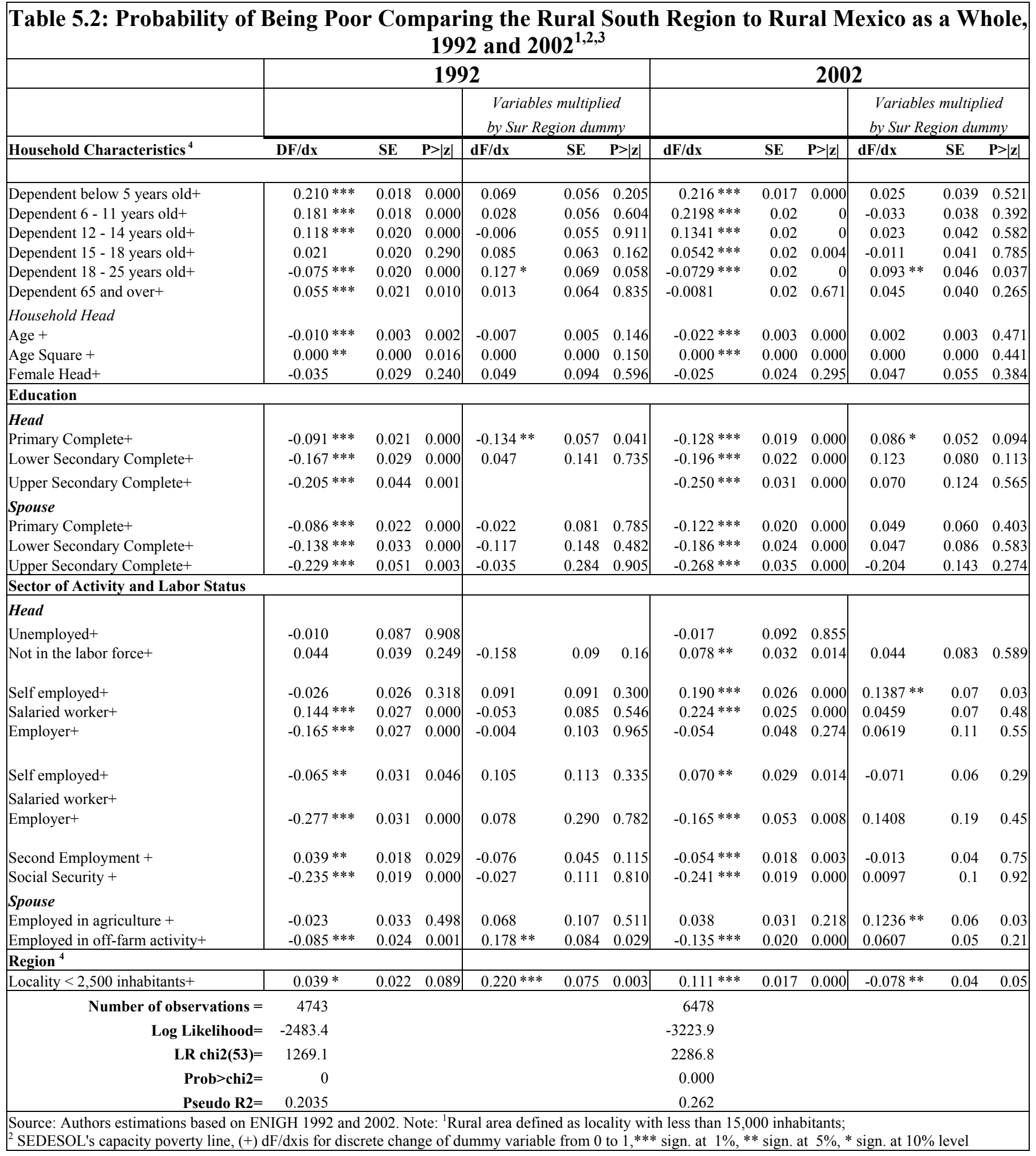


Household heads that are inactively participating in the labor force are more likely to experience poverty than their peers being active in the labor force in 2002. In the early and mid-1990s this was not the case, as there was no statistically difference in the likelihood of falling into poverty for the two groups. Surprisingly, unemployed household heads in rural Mexico have neither a smaller or larger likelihood of being poor than their working peers. Findings in Table 5.1 indicate that this holds for both 1992 and 2002, but not after the crises in 1996 where unemployed heads were more likely to experience poverty than their employed peers. Part of the explanation may be increased remittances (Appendix B).

Employers are the single group that has the lowest probability of being poor followed by self-employed and salaried workers. In 2002, employers in non-agricultural related activities were 14 percentage points less likely to be poor than salaried workers; down from 26 percent points in 1992 and 36 percentage points in 1996. In 1992, the self-employed household heads were 4 percentage points less likely to experience poverty than their salaried worker peers in the off-farm sector. By 2002, this finding had changed so self-employed household heads were not marginally more or less poverty prone than were salaried workers in the non-agricultural sector. In 1992 self-employed in agriculture was not worse of than wageworkers in the nonfarm sector, although they were 4-percentage point more likely to experience poverty than self-employed in the nonfarm sector. During 1992-2002, the selfemployed in agriculture experienced a 22-percentage-points increase in the likelihood of experiencing poverty. In 2002 relative to salaried workers in agriculture, the self-employed were not significantly more likely to experience or escape poverty, controlling for other characteristics, although they were in 1992.

Salaried workers in the agricultural sector experienced an increase of 5-percentage points in the likelihood of being poor during 1992-2002 compared to their peers in the nonfarm sector. Moreover, household heads with spouse engaged in the off-farm sector experienced a lower probability of being poor than did household heads with spouse engaged in agriculture or not working at all. Moreover this finding became stronger throughout the 1992-2002 period and in 2002 household heads with spouse engaged in off-farm activities had a 13-percentage points lower likelihood of experiencing poverty. Also, Araujo (2003) addresses the impact of non-farm rural employment on poverty. Araujo uses municipality data and finds that in Mexican municipalities there is a negative effect of manufacturing and services employment on poverty in semi-urban municipalities and a negative effect of services employment on poverty in rural municipalities.

In the 1990s, heads of household that took a second job were neither more nor less likely to escape poverty than their peers that did not take on an extra job, but in 2002 the second job holders were 6 percentage points more likely to escape poverty than heads that did not take a second job. Hence, the effect of the second job became poverty reducing after 1996 and hence a way that some rural families managed to escape or reduce household poverty.

When comparing the likelihood of being poor for household heads with different labor status in the South region to Mexico as a whole, the findings show that only self-employed southerners in the agricultural sector are statistically significantly more likely to be poor (14 percentage points) than in the rest of the country in 2002. In 1992 there was no difference 
between self-employed workers in agriculture in the South and the rest of Mexico. Also, when a southern spouse is employed in agriculture, the household is more likely to be poor (13 percentage points) than households where the spouse is employed in agriculture but living in another part of the country. This finding may relate to the fact that in the South region there is only one crop season due to lack of irrigation infrastructure. Other activities and occupations do not show results that are statistically different to the rest of Mexico for that particular category of labor or sector.

\section{Education and Skills}

In rural Mexico as in many other developing countries, one of the most important factors contributing to the probability of a household being poor is human capital. Findings in Table 5.1 reveal that completed level of education by the household head and spouse are both very important to escape poverty. That is, the more education a household head and spouse have completed, the lower the probability of earning an income that takes the household below the poverty line. All education variables in the three models are strongly, statistically significant, and negatively correlated with the probability of being poor. This is the case for all levels of education starting with completed primary education. Controlling for other variables, the impact of educational attainment is quantitatively among the largest of all included explanatory variables. Moreover, the negative effect of education on poverty (i.e. the positive effect for poverty reduction) is increasing with the level of completed education of the household head and for the spouse. Put differently, the more completed education the less likely it is that the household experience poverty in rural Mexico. ${ }^{8}$

Relatively to the uneducated, those with education are generally more likely to escape poverty. Findings reveal that the impact of having raised one's completed level of education to the primary level on the likelihood of escaping poverty has been rather constant, around 10 percentage points over the last decade. For completed lower secondary education, the magnitude of estimated impacts is larger than completed primary. During 1992-2002, household heads that had completed lower secondary education experienced 18 percentage points lower probability of falling into poverty than their peers with no level of completed education. The effect on poverty of completed upper secondary education is significantly higher than for the other levels of education. Table 5.1 shows that the impact on poverty of completed upper secondary education is significantly and numerically larger, hence more poverty reducing than that of lower secondary education. The impact on the likelihood of escaping poverty of having completed secondary education in 2002 reached 24 percentage points relative to not having completed any level of education, in line with the impact in 1992 but down from 34 percentage points in 1996.

\footnotetext{
${ }^{8}$ Also Ferreira, Lanjouw and Neri (1999) in the analysis of Brazil finds that education is the central personal attribute determining the likelihood that a household experience poverty.
} 


\begin{tabular}{|c|c|c|c|c|c|c|c|c|c|}
\hline \multicolumn{10}{|l|}{ Table 5.3: } \\
\hline \multirow{4}{*}{$\begin{array}{r}\text { Number of observations }= \\
\text { Prob }>\mathbf{F}= \\
\text { R-squared }= \\
\text { Adj R-squared }=\end{array}$} & \multirow{2}{*}{$\begin{array}{r}4750 \\
0.000\end{array}$} & \multicolumn{3}{|r|}{6160} & \multicolumn{3}{|r|}{6473} & & \\
\hline & & \multicolumn{3}{|r|}{0.000} & \multicolumn{3}{|r|}{0.000} & & \\
\hline & 0.384 & \multicolumn{3}{|r|}{0.432} & \multicolumn{3}{|r|}{0.453} & & \\
\hline & 0.380 & & & 0.429 & \multicolumn{3}{|r|}{0.450} & & \\
\hline \multirow[t]{2}{*}{ Log income } & \multicolumn{3}{|c|}{1992} & \multicolumn{3}{|c|}{1996} & \multicolumn{3}{|c|}{2002} \\
\hline & Coeff. & SE & $\mathbf{P}>|\mathbf{t}|$ & Coeff. & SE & $\mathbf{P}>|\mathbf{t}|$ & Coeff. & SE & $\mathbf{P}>|\mathbf{t}|$ \\
\hline \multicolumn{10}{|l|}{ Household Characteristics $^{3}$} \\
\hline Dependent below 5 years old + & $-0.390 * * *$ & 0.023 & 0.000 & $-0.356 * * *$ & 0.019 & 0.000 & $-0.394 * * *$ & 0.019 & 0.000 \\
\hline Dependent $6-11$ years old + & $-0.355 * * *$ & 0.022 & 0.000 & $-0.397 * * *$ & 0.018 & 0.000 & $-0.352 * * *$ & 0.018 & 0.000 \\
\hline Dependent $12-14$ years old + & $-0.180 * * *$ & 0.024 & 0.000 & $-0.213 * * *$ & 0.020 & 0.000 & $-0.205 * * *$ & 0.020 & 0.000 \\
\hline Dependent $15-18$ years old + & $-0.069 * * *$ & 0.025 & 0.005 & $-0.086 * * *$ & 0.020 & 0.000 & $-0.124 * * *$ & 0.020 & 0.000 \\
\hline Dependent $18-25$ years old + & $0.049 *$ & 0.025 & 0.055 & $0.057 * * *$ & 0.021 & 0.006 & $0.035 *$ & 0.021 & 0.094 \\
\hline $\begin{array}{l}\text { Dependent } 65 \text { and over+ } \\
\text { Household Head }\end{array}$ & $-0.094 * * *$ & 0.026 & 0.000 & $-0.051 * *$ & 0.022 & 0.020 & -0.016 & 0.021 & 0.445 \\
\hline Age + & $0.025 * * *$ & 0.004 & 0.000 & $0.033 * * *$ & 0.004 & 0.000 & $0.037 * * *$ & 0.004 & 0.000 \\
\hline Age Square + & $0.000 * * *$ & 0.000 & 0.000 & $0.000 * * *$ & 0.000 & 0.000 & $0.000 * * *$ & 0.000 & 0.000 \\
\hline Female Head + & 0.035 & 0.037 & 0.346 & $0.147 * * *$ & 0.029 & 0.000 & $0.078 * * *$ & 0.026 & 0.003 \\
\hline \multicolumn{10}{|l|}{\begin{tabular}{|l|} 
Education \\
\end{tabular}} \\
\hline \multicolumn{10}{|l|}{ Head } \\
\hline Primary Complete+ & $0.235 * * *$ & 0.028 & 0.000 & $0.187 * * *$ & 0.023 & 0.000 & $0.226 * * *$ & 0.023 & 0.000 \\
\hline Lower Secondary Complete+ & $0.416 * * *$ & 0.046 & 0.000 & $0.370 * * *$ & 0.034 & 0.000 & $0.344 * * *$ & 0.031 & 0.000 \\
\hline $\begin{array}{l}\text { Upper Secondary Complete }+ \\
\text { Spouse }\end{array}$ & $0.809 * * *$ & 0.065 & 0.000 & $0.706 * * *$ & 0.045 & 0.000 & $0.672 * * *$ & 0.043 & 0.000 \\
\hline Primary Complete + & $0.105 * * *$ & 0.030 & 0.000 & $0.087 * * *$ & 0.024 & 0.000 & $0.127 * * *$ & 0.024 & 0.000 \\
\hline Lower Secondary Complete+ & $0.172 * * *$ & 0.047 & 0.000 & $0.206 * * *$ & 0.036 & 0.000 & $0.195 * * *$ & 0.033 & 0.000 \\
\hline Upper Secondary Complete + & $0.517 * * *$ & 0.082 & 0.000 & $0.522 * * *$ & 0.058 & 0.000 & $0.529 * * *$ & 0.053 & 0.000 \\
\hline \multicolumn{10}{|l|}{ Sector of Activity and Labor Status } \\
\hline \multicolumn{10}{|l|}{ Head } \\
\hline Unemployed + & $-0.218 *$ & 0.119 & 0.068 & $-0.415 * * *$ & 0.091 & 0.000 & $-0.215 * *$ & 0.110 & 0.049 \\
\hline $\begin{array}{l}\text { Not in the labor force }+ \\
\text { Agro pecuarian Sector }\end{array}$ & -0.033 & 0.048 & 0.483 & $-0.093 * *$ & 0.039 & 0.017 & $-0.090 * *$ & 0.035 & 0.011 \\
\hline Self employed + & 0.032 & 0.033 & 0.332 & $-0.073 * *$ & 0.029 & 0.011 & $-0.264 * * *$ & 0.028 & 0.000 \\
\hline Salaried worker+ & $-0.240 * * *$ & 0.032 & 0.000 & $-0.192 * * *$ & 0.028 & 0.000 & $-0.260 * * *$ & 0.027 & 0.000 \\
\hline $\begin{array}{l}\text { Employer+ } \\
\text { Off-farm Sector }\end{array}$ & $0.398 * * *$ & 0.043 & 0.000 & $0.305 * * *$ & 0.040 & 0.000 & $0.313 * * *$ & 0.051 & 0.000 \\
\hline $\begin{array}{l}\text { Self employed }+ \\
\text { Salaried worker+ }\end{array}$ & $0.081 * *$ & 0.041 & 0.049 & 0.049 & 0.033 & 0.141 & 0.004 & 0.031 & 0.903 \\
\hline Employer+ & $0.702 * * *$ & 0.081 & 0.000 & $0.672 * * *$ & 0.058 & 0.000 & $0.513 * * *$ & 0.061 & 0.000 \\
\hline Second Employment + & $0.054 * *$ & 0.022 & 0.012 & $0.059 * * *$ & 0.019 & 0.002 & $0.112 * * *$ & 0.020 & 0.000 \\
\hline $\begin{array}{l}\text { Social Security }+ \\
\text { Spouse }\end{array}$ & $0.292 * * *$ & 0.033 & 0.000 & $0.350 * * *$ & 0.030 & 0.000 & $0.315 * * *$ & 0.028 & 0.000 \\
\hline Employed in agriculture + & -0.023 & 0.042 & 0.585 & -0.008 & 0.030 & 0.783 & $-0.073 * *$ & 0.030 & 0.016 \\
\hline Employed in off-farm activity + & $0.090 * * *$ & 0.031 & 0.004 & $0.154 * * *$ & 0.024 & 0.000 & $0.206 * * *$ & 0.022 & 0.000 \\
\hline Region & & & & & & & & & \\
\hline Norte + & $0.274 * * *$ & 0.035 & 0.000 & $0.288 * * *$ & 0.032 & 0.000 & $0.063 * *$ & 0.030 & 0.032 \\
\hline Capital+ & 0.086 & 0.056 & 0.122 & 0.028 & 0.057 & 0.622 & 0.028 & 0.034 & 0.407 \\
\hline Golfo + & -0.045 & 0.034 & 0.178 & $-0.130 * * *$ & 0.027 & 0.000 & $-0.288 * * *$ & 0.028 & 0.000 \\
\hline Pacifico + & $0.253 * * *$ & 0.034 & 0.000 & $0.234 * * *$ & 0.030 & 0.000 & -0.043 & 0.030 & 0.153 \\
\hline Sur+ & $-0.183 * * *$ & 0.036 & 0.000 & $-0.214 * * *$ & 0.028 & 0.000 & $-0.292 * * *$ & 0.027 & 0.000 \\
\hline Centro+ & $-0.086 * * *$ & 0.031 & 0.006 & $-0.131 * * *$ & 0.029 & 0.000 & $-0.238 * * *$ & 0.029 & 0.000 \\
\hline Locality $<2,500$ inhabitants + & $-0.116 * * *$ & 0.028 & 0.000 & $-0.140 * * *$ & 0.019 & 0.000 & $-0.127 * * *$ & 0.019 & 0.000 \\
\hline Constant & $4.909 * * *$ & 0.108 & 0.000 & $5.306 * * *$ & 0.092 & 0.000 & $6.049 * * *$ & 0.093 & 0.000 \\
\hline
\end{tabular}




\begin{tabular}{|c|c|c|c|c|c|c|c|}
\hline \multicolumn{8}{|c|}{$\begin{array}{l}\text { Table 5.4: Years of Completed Education for Age Groups, by } \\
\text { Locality and Poverty Condition, Selected Years 1992-2002 }\end{array}$} \\
\hline & & \multicolumn{2}{|c|}{1992} & \multicolumn{2}{|c|}{1996} & \multicolumn{2}{|c|}{2002} \\
\hline & & Poor & $\begin{array}{l}\text { Non- } \\
\text { poor }\end{array}$ & Poor & $\begin{array}{l}\text { Non- } \\
\text { poor }\end{array}$ & Poor & $\begin{array}{l}\text { Non- } \\
\text { poor }\end{array}$ \\
\hline Region & \multicolumn{7}{|c|}{ Age group 12-24 } \\
\hline \multirow[t]{4}{*}{ Rural $^{1}$} & No education & 12.71 & 5.72 & 7.85 & 5.48 & 5.27 & 4.25 \\
\hline & Primary incomplete & 40.27 & 27.48 & 34.46 & 16.47 & 21.57 & 14.19 \\
\hline & Primary complete & 38.77 & 41.87 & 43.13 & 44.06 & 51.12 & 42.51 \\
\hline & Secondary complete & 7.87 & 21.8 & 13.69 & 29.6 & 20.53 & 30.45 \\
\hline \multirow{6}{*}{ Urban } & Higher education & 0.37 & 3.13 & 0.88 & 4.39 & 1.52 & 8.59 \\
\hline & No education & 6.63 & 2.85 & 3.64 & 2.94 & 5.66 & 1.75 \\
\hline & Primary incomplete & 24.9 & 9.48 & 19.55 & 5.73 & 22.41 & 5.28 \\
\hline & Primary complete & 46.55 & 33.73 & 43.77 & 30.77 & 41.56 & 30.56 \\
\hline & Secondary complete & 20.7 & 39.14 & 28.28 & 41.39 & 25.29 & 39.22 \\
\hline & Higher education & 1.22 & 14.8 & 4.76 & 19.16 & 5.08 & 23.19 \\
\hline \multicolumn{8}{|c|}{ Age group 25-45 } \\
\hline \multirow[t]{5}{*}{ Rural } & No education & 37.67 & 20.9 & 21.67 & 13.09 & 23.15 & 12.84 \\
\hline & Primary incomplete & 43.66 & 40.75 & 44.57 & 30.41 & 39.14 & 27.49 \\
\hline & Primary complete & 16.66 & 27.34 & 25.62 & 29.85 & 29.26 & 31.37 \\
\hline & Secondary complete & 1.96 & 7.74 & 7.46 & 18.77 & 7.32 & 19.55 \\
\hline & Higher education & 0.04 & 3.26 & 0.67 & 7.89 & 1.13 & 8.76 \\
\hline \multirow[t]{5}{*}{ Urban } & No education & 19.27 & 6.37 & 12.13 & 4.25 & 11.79 & 3.18 \\
\hline & Primary incomplete & 34.93 & 16.37 & 29.11 & 10.46 & 26.13 & 9.28 \\
\hline & Primary complete & 35.85 & 29.28 & 36.7 & 22.6 & 31.96 & 21.04 \\
\hline & Secondary complete & 8.68 & 24.06 & 17.3 & 30.45 & 25.07 & 34.05 \\
\hline & Higher education & 1.27 & 23.9 & 4.77 & 32.23 & 5.05 & 32.44 \\
\hline
\end{tabular}

The probability of falling below the poverty line fell for secondary school graduates during 1992-1996 and increased again from 1996-2002 reaching a level that is not statistically significantly different from 1992. As unemployment increased after the crises in 1996, the labor market returns adjusted a little, as can be noticed in Table 5.3. The income per capita regression analyses presented confirm that returns to secondary education decreased before the crises and decreased only slightly again during 1996-2002. Moreover, the head of household's returns to secondary education in rural areas were statistically and significantly lower in 2002 (67 percent) than in 1992 (81 percent), controlling for other individual and household characteristics.

Human capital is composed of many components and an important one, apart from formal education, is skills. In the labor market literature, skills and experience are often proxied by the age of a worker. We include the age and age squared in the regression, the latter to capture possible nonlinearities in data. In all models, age is positively associated with the probability of escaping poverty during 1992-2002. Moreover, during this period skills become more poverty reducing; one more year decreases the likelihood of experiencing 
poverty by 2 percentage points in 2002 up from less than 1 percentage point in 1992 . There does not seem to be a turning point at an older age where the probability of being poor increases since the age-squared variable is estimated to be not statistically significantly different from zero. Hence, there does not seem to be any nonlinearity present in skills and experience in rural Mexico. This indicates that the older the household head, the lower probability the household will be poor controlling for other variables.

\section{Gender}

The gender of the household head makes a statistically significant difference for poverty in the mid-1990s where female-headed households were less likely to be poor than male-headed households. The finding was also present in 2002, but not statistically different from zero. In 1992 and 2002, the probability of female-headed households experiencing poverty is not different to that of male-headed households at a five percent level when including other covariates in the analysis, such as labor market connection, education, etc. in rural Mexico. This finding is different from other countries, such as Brazil, where male heads have a lower probability of being poor than female heads do.

\section{Household Structure}

Findings reveal that the household structure is more important than the age of the household head, since other included family characteristics are strongly statistically significant in explaining the likelihood of experiencing poverty for all years and the impact is also large than for age of the household head in rural Mexico.

The presence of children or youth in the household makes it more poverty prone. The presence of young children below the age of 5 makes the household more likely to fall into poverty than households with no children and children or youth age 6-24. The Probit regression findings reveal that the probability of being poor falls monotonically with increased child age. Households with members under the age of 5 appear more likely to be poor than families with no children below age 5. This finding indicates that households with young children are more vulnerable than households with no children below the age of five. Furthermore, the probability of experiencing poverty for families with small children has been high and rather constant over the past decade. One direct policy intervention would be to facilitate access to childcare. In particular, the poor often find the shortage of affordable childcare a large obstacle to their daily chores.

Also, households with members between the age of 6 and 11 have a large probability of being poor, albeit the likelihood is slightly lower than for families with small children. The probability of being poor increased from 17-percentage points in 1992 to 25 percentage points in 1996 and fell again to 22-percentage points in 2002 for households with children age 6 to 11 compared to households with no children. Households with youth members aged 15-18 experienced the same pattern in the likelihood of experiencing poverty as households with 611 year olds, although the impact is significantly smaller reaching 6-percentage point in 2002. One explanation for these findings may be that the introduction of Progresa in rural Mexico had a poverty reducing effect for households with children age 6-18. 
The picture changes dramatically when the age of the youth household members increases to 19-25 years. During 1992-2002, households with members aged 19-25 are significantly less likely to fall below the poverty line than households with no children or youth present, controlling for other variables. Therefore, household members aged 19-25 can be considered a protective factor against poverty as these households have a 6 percentage points lower probability of being poor than households with no children. The fact that many youth enter into the labor market and bring home an income contributes positively to the household's poverty situation. In 2002, households in the South region that have youth household members do not experience the same lower probability of experiencing poverty as does Mexico as a whole, but it did in 1992 (Table 5.2). This may indicate that the most capable migrate and only the less educated and skilled stay behind, however this needs more investigation.

The presence of an older household member (above 65 years of age) in the households led it to become less poverty prone during 1992-2002. The presence of a household member age 65 and above was significantly and positively correlated with poverty in the 1990s. That is, having an old-aged in the household implied a higher chance of falling below the poverty line. In 2002, households with members of old age did continue to experience a higher likelihood of poverty but the magnitude was lower; 0.4-percentage points in 2002 compared to 5 percentage points in 1992 .

\section{Regions}

Regional differences in probabilities of experiencing poverty require policy makers to address these differences. In this section we do not go very deep in trying to assess regional differences in the likelihood of being poor between different regions in Mexico, but some regional differences are noteworthy. During 1992-2002, rural households in all regions experienced an increased probability of falling into poverty relative to those in the CenterNorth region. Relative to those living in the Center-North region, the population in the North, Pacific, Capital, and Center regions in general are less likely to experience poverty, controlling for other variables. The Probit regression findings in Table 5.1 also reveal that heads of households in the Gulf, Center, and South regions of Mexico were more likely to experience poverty than the Center-North throughout the 1992-2002 period. None of these regions improved their chances of escaping poverty during the decade, controlling for other variables. In 2002, household heads living in the South and Gulf regions had a roughly 20percentage-points higher likelihood of falling below the poverty line than their peers in the Center-North region.

\section{Other considerations}

By no means is this analysis fully complete, as important information identified by the poor themselves in rural Mexico is not directly included in the analysis, for example, safety, peace of mind, good health, sustainable environment, belonging to a community, and freedom of choice and action. In particular, crime, violence and safety are flagged as important problems and obstacles to well-being in the poor communities. 
The ENIGH data set does not contain any information on ethnic or racial background. Other studies on poverty such as Finan, Sadoulet, and de Janvry (2002) measure the poverty reduction potential of land in rural Mexico using household data gathered in 1997 by the Mexican program for Education, Health, and Nutrition. Their results show for small landholders, an additional hectare of land increases welfare on average by 1.3 times the earnings of an agricultural worker. In addition, the marginal welfare value of land depends importantly on a household's control over complementary assets and on the context where assets are used: For non-indigenous small farmers with at least primary education and access to a road, the welfare benefit of additional land is on average seven times higher than for those without these attributes. Social assets such as ethnicity lower the marginal value of land, whereas households with more education receive a higher return to land. Households that face lower transactions costs as measured by assess to roads, garner a return to land that is two to three times as high as those without access to a road. These findings suggest that land can indeed be an important element of a poverty reduction strategy, but that there are specific conditions that must hold for this to be the case, calling on complementary interventions in Mexico.

Moreover, the ENIGH datasets do not contain any information on ethnic or racial background. Other studies on poverty in Latin America have shown that ethnic or racial background is an important factor contributing to poverty, controlling for other household head characteristics. Mestizos and Indians are two broad ethnic groups based on cultural rather than racial differences cohabiting in Mexico. Each group has a distinct cultural viewpoint and perceives itself as different from the other. At the same time, however, group allegiances may change, making measurement of ethnic composition problematic at best. Originally racial designators the terms Mestizo and Indian have lost almost their entire previous racial connotation and are now used entirely to designate cultural groups.9 Although matzos and indians may both reside in rural areas and have relatively comparable levels of income, they maintain different lives, e.g. Mestizos often argue that Indians are too unmotivated and constrained by tradition to deal appropriately with the demands of modern society. Indians, in turn, frequently argue that mestizos are aggressive, impatient, and disrespectful toward nature.

In 1990, 7.5 percent of the Mexican population, or approximately 5.3 million people above five years of age, spoke an Indian language. Of that total, approximately 79 percent knew Spanish as well and thus were at least potential cultural converts to the mestizo world. Familiarity with indigenous languages increases from north to south: almost no native speakers live in the northeast and north-central part of Mexico, the share climbed to between 10-20 percent in the grouping of states from San Luis Potosí to Guerrero, to 26 percent in Oaxaca, to 32 and 39 percent, respectively, in Quintana Roo and Chiapas, and to 44 percent in Yucatán. Only 63 percent of users of indigenous languages in Chiapas also knew Spanish.

\footnotetext{
${ }^{9}$ Historically, the term mestizo described someone with mixed European and indigenous heritage. Mestizos occupied a middle social stratum between whites and pureblooded indigenous people.
} 
According to the 1990 Census, Indians remain the most marginalized group of Mexican society. More than 40 percent of the Indian population above fifteen years of age was illiterate; roughly three times the national rate. Thirty percent of Indian children between 6-14 years of age did not attend school. Indians also had significantly higher morbidity and mortality rates associated with infectious and parasitic illnesses, higher levels of nutritional deficiencies, and less access to such basic services such as indoor plumbing, piped water, and electricity.

\section{Poverty-Reduction Strategy for Rural Mexico}

Over the medium to long run, what is needed to alleviate the high levels of poverty is broad-based growth. However, this is not enough to alleviate poverty, particularly in the short run. Measures are needed to protect vulnerable groups and to ensure that the rural poor are able to take advantage of the greater opportunities in the economy. In order to address these latter needs, this paper has examined the profile of the poor in rural Mexico and the rural poverty correlates.

The government of Mexico has taken important steps to reduce poverty, for example though the continuation of Oportunidades. However, it needs a rural poverty alleviation strategy that sets clear and appropriate priorities and goals for poverty reduction efforts within a framework of a continuation of economic policies that would promote growth. The challenge and test of the government's resolve will be to what extent current and future policies and programs are governed by that strategy. In order to ensure that the poor reap the benefits, poverty measurement and monitoring are called for, including tracking changes and making appropriate adjustments in existing programs to reflect these changes.

\section{A THREE-PRONGED POVERTY-REDUCTION APPROACH FOR MEXICO}

The differing characteristics of poor households call for multiple paths out of poverty aimed at: (i) small farm sector intensification, (ii) improved employment opportunities in dynamic commercial agriculture, (iii) growth of the rural non-farm sector, (iv) migration of the young, and (v) provision of safety nets for those "trapped" in poverty. The recommended measures include improving human capital endowments, reforming the land, labor and financial markets, enhancing research and extension, improving the supply of public goods and services, and transfer programs.

The rural poverty profile and determinants of poverty analysis provide guidance on a social agenda and poverty alleviation strategy for rural Mexico. The strategic principles for reducing poverty involve seeking to strengthen the key assets of the poor, taking into account geographic differences in the poverty situation and priorities.

The government of Mexico could apply a three-pronged poverty-reduction approach:

First, targeted programs should focus on the extreme poor and prioritize among groups in rural areas, especially in the dispersed rural areas. Given the distribution of poverty, first 
priority should be given to: households with young children and people with or at risk for low education attainment.

Second, priority should be assigned to programs that target the poor informal-sector workers and the poor unemployed. Improvements in social policies and access to public services are needed to reduce extreme poverty for these groups.

- The young children finding indicates that households with small children are far more likely to experience poverty than, for example, households with no children or older children or youth. Social policies should be expanded, for example: (1) conditionalcash-transfer programs where the mother receives the benefit, and (2) more kindergarten and childcare facilities for poor mothers could facilitate poor, especially, women's labor market participation.

- Extremely poor households are at great risk for poor or low human capital accumulation that includes poor health and undesired pregnancies because they lack access to family planning and clean water and sanitation facilities. They are also at risk for low-quality education and education attainment. Increased quality education and educational attainment can reduce the likelihood of becoming poor, as more education is a key factor in obtaining a higher income. Furthermore, education is associated with fertility: the more education a woman attains, the lower her fertility rate and, therefore, the lower the dependency ratio and the lower the likelihood of falling into poverty. It is clear that the rural population in Mexico needs to be brought up the educational ladder to escape poverty. One approach would be to increase: (1) access to early childhood development and daycare programs, (2) access of poor people to programs of financial transfers linked to early childhood development and secondary and higher education, and (3) the quality of education.

Third, other households are poor because they are either in low-paying, low-productivity jobs in the informal sector or unemployed. They need more productive jobs to raise their income above the poverty level and become well equipped to take advantage of employment opportunities. It should be recognized that since very few people work in the formal labor market, social policies tied to formal employment or unemployment will have only very limited reach among the poor. Social protection policies need to allow informal workers to avail of them, while simultaneous efforts need to be made to encourage formal sector growth and that may include liberalization of the labor market. Hence, the government should support initiatives to reform the labor code in order to reduce costs of employment creation in the formal sector. Possible measures would entail: (1) realigning incentives for hiring, retaining, and firing workers, and (2) targeted social protection measures that relate to informal sector and youth employment. 


\section{REFERENCES}

Araujo (2003)

Blom, Andreas, and Carlos Vélez. 2001. "The Dynamics of the Skill-premium in Brazil; Growing Demand and Insufficient Supply?" Washington, D.C.: World Bank.

Blom, Andreas, Nina Pavcnik, and Norbert Schady. 2001. "Trade Liberalization and Labor Market Adjustment in Brazil." Washington, D.C.: World Bank.

Ferreira and Leite, 2001. "Education Expantion and Income Distribution", http://www.nipnetwork.org/panama_meeting_2002/leite.pdf.

Ferreira, Francisco, Peter Lanjouw, and Marcelo Neri. 1998. "The Urban Poor in Brazil in 1996: A New Poverty Profile Using PPV, PNAD and Census Data." A Background Paper for the World Bank's Urban Poverty Strategy Report.

Finan, F., E. Sadoulet, and A.de Janvry (2002) "Measuring the Poverty Reduction Potential of Land in Rural Mexico", University of California at Berkeley. Mimio.

Foster, Greer, and Thorbecke (1984). "A class of decomposable poverty measures." Econometrica, 52, 761-65.

Elbers, C., J. Olson Lanjouw, P. Lanjouw and P. G. Leite (2001). "Poverty and Inequality in Brazil: Estimates from Combined PPV-PNAD Data." World Bank mimeo.

Heckman, James. 1999. "Policies to Foster Human Capital." Working Paper No. 7288. Cambridge, MA: National Bureau of Economic Research, August.

—. 2001. "World Development Report 2000/2001." Washington, D.C. 


\section{Appendix A: Population in Mexico by size of Locality, 1990, 1990, and 2002}

\section{State} $<\mathbf{2 , 5 0 0}>\mathbf{2 , 5 0 0}<\mathbf{1 5 , 0 0 0}>\mathbf{1 5}, 000$

$289,92457,959,72134$

Aguascalientes

Baja California

Baja California Sur

Campeche

Coahuila de Zaragoza

Colima

Chiapas

Chihuahua

Distrito Federal

Durango

Guanajuato

Guerrero

Hidalgo

Jalisco

México

Michoacán de Ocampo

Morelos

Nayarit

Nuevo León

Oaxaca

Puebla

Querétaro de Arteaga

Quintana Roo

San Luis Potosí

Sinaloa

Sonora

Tabasco

Tamaulipas

Tlaxcala

Veracruz Llave

Yucatán

Zacatecas

\section{$168,962 \quad 550,697$}

$151,061 \quad 1,509,794$

$69,099 \quad 248,665$

$160,405 \quad 374,780$

$275,019 \quad 1,697,321$

$71,476 \quad 357,034$

$1,913,754 \quad 1,296,742 \quad 2,45$

$552,107 \quad 1,889,766$

$21,901 \quad 8,213,843$

$574,961 \quad 774,417$

$1,457,060 \quad 2,525,533 \quad 1,84$

$\begin{array}{llllll}9,369,536 & 1,686,609 & 934,028 & 2,620,637\end{array}$

$1,042,648 \quad 845,718 \quad 1,402,800 \quad 485,566 \quad 1,888,366$

$\begin{array}{llllll}962,257 & 4,340,432 & 1,727,958 & 3,574,731 & 5,302,689\end{array}$

$\begin{array}{llllll}1,530,588 & 8,285,207 & 2,818,072 & 6,997,723 & 9,815,795\end{array}$

$\begin{array}{llllll}1,361,845 & 2,186,354 & 2,108,956 & 1,439,243 & 3,548,199\end{array}$

$\begin{array}{lllll}171,831 & 1,023,228 & 532,762 & 662,297 & 1,195,059\end{array}$

$\begin{array}{lllll}312,912 & 511,731 & 507,386 & 317,257 & 824,643\end{array}$

$\begin{array}{llllll}248,079 & 2,850,657 & 398,146 & 2,700,590 & 3,098,736\end{array}$

$\begin{array}{llllll}1,828,257 & 1,191,303 & 2,417,582 & 601,978 & 3,019,560\end{array}$

$\begin{array}{llllll}1,473,322 & 2,652,779 & 2,462,697 & 1,663,404 & 4,126,101\end{array}$

$\begin{array}{llllll}423,396 & 627,839 & 561,827 & 489,408 & 1,051,235\end{array}$

$\begin{array}{llllll}128,903 & 364,374 & 197,505 & 295,772 & 493,277\end{array}$

$\begin{array}{llllll}898,164 & 1,105,023 & 1,137,373 & 865,814 & 2,003,187\end{array}$

$\begin{array}{llllll}791,607 & 1,412,447 & 1,151,079 & 1,052,975 & 2,204,054\end{array}$

$\begin{array}{llllll}380,539 & 1,443,067 & 597,571 & 1,226,035 & 1,823,606\end{array}$

$\begin{array}{llllll}756,026 & 745,718 & 1,025,991 & 475,753 & 1,501,744\end{array}$

$\begin{array}{lllll}425,877 & 1,823,704 & 598,859 & 1,650,722 & 2,249,581\end{array}$

$\begin{array}{lllll}178,926 & 582,351 & 493,330 & 267,947 & 761,277\end{array}$

\begin{tabular}{lllll|l}
$2,726,513$ & $3,501,726$ & $3,789,568$ & $2,438,671$ & $6,228,239$ & 2,8
\end{tabular}

$\begin{array}{lllll}291,322 & 1,071,618 & 603,533 & 759,407 & 1,362,940\end{array}$ $\begin{array}{lllll}690,006 & 586,317 & 947,021 & 329,302 & 1,276,323\end{array}$

\section{0}

19952000

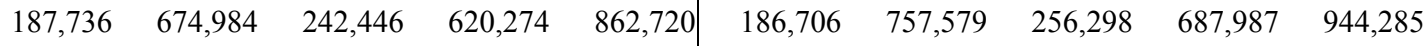

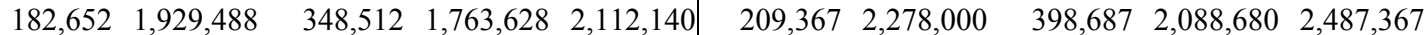
\begin{tabular}{lllll|lllll}
79,159 & 296,335 & 135,513 & 239,981 & 375,494 & 79,306 & 344,735 & 156,412 & 267,629 & 424,041
\end{tabular} \begin{tabular}{|lllll|lllll|}
185,321 & 457,195 & 302,893 & 339,623 & 642,516 & 200,380 & 490,309 & 324,906 & 365,783 & 690,689 \\
\hline
\end{tabular}

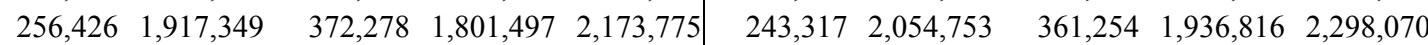
$\begin{array}{llllllllll}72,044 & 415,984 & 148,360 & 339,668 & 488,028 & 78,189 & 464,438 & 161,926 & 380,701 & 542,627\end{array}$ \begin{tabular}{lllll|lllll}
$2,002,394$ & $1,582,392$ & $2,609,416$ & 975,370 & $3,584,786$ & $2,129,034$ & $1,791,858$ & $2,799,203$ & $1,121,689$ & $3,920,892$
\end{tabular} \begin{tabular}{lllll|lllll}
554,353 & $2,239,184$ & 742,378 & $2,051,159$ & $2,793,537$ & 533,460 & $2,519,447$ & 750,499 & $2,302,408$ & $3,052,907$
\end{tabular} \begin{tabular}{lllll|lllll}
25,146 & $8,463,861$ & 121,220 & $8,367,787$ & $8,489,007$ & 20,320 & $8,584,919$ & 100,491 & $8,504,748$ & $8,605,239$
\end{tabular} \begin{tabular}{|lllll|lllll}
558,781 & 872,967 & 749,217 & 682,531 & $1,431,748$ & 524,606 & 924,055 & 710,770 & 737,891 & $1,448,661$
\end{tabular} \begin{tabular}{lllll|lllll}
$1,470,634$ & $2,935,934$ & $1,901,685$ & $2,504,883$ & $4,406,568$ & $1,529,249$ & $3,133,783$ & $1,941,141$ & $2,721,891$ & $4,663,032$
\end{tabular} $\begin{array}{llllllllll}1,321,742 & 1,594,825 & 1,802,262 & 1,114,305 & 2,916,567 & 1,376,446 & 1,703,203 & 1,878,627 & 1,201,022 & 3,079,649\end{array}$ \begin{tabular}{lllll|llllll}
$1,109,584$ & $1,002,889$ & $1,501,534$ & 610,939 & $2,112,473$ & $1,132,897$ & $1,102,694$ & $1,551,581$ & 684,010 & $2,235,591$
\end{tabular} \begin{tabular}{lllll|lllll}
$1,007,468$ & $4,983,708$ & $1,820,041$ & $4,171,135$ & $5,991,176$ & 976,700 & $5,345,302$ & $1,810,919$ & $4,511,083$ & $6,322,002$
\end{tabular}

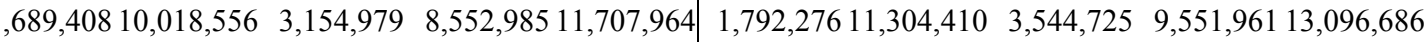
$\begin{array}{lllllllllll}1,373,161 & 2,497,443 & 2,193,754 & 1,676,850 & 3,870,604 & 1,378,901 & 2,606,766 & 2,235,229 & 1,750,438 & 3,985,667\end{array}$ \begin{tabular}{llllll|llll}
203,334 & $1,239,328$ & 588,521 & 854,141 & $1,442,662$ & 226,574 & $1,328,722$ & 631,584 & 923,712 & $1,555,296$
\end{tabular} \begin{tabular}{lllll|lllll}
331,772 & 564,930 & 509,379 & 387,323 & 896,702 & 329,757 & 590,428 & 535,355 & 384,830 & 920,185 \\
\end{tabular} \begin{tabular}{lllll|lllll}
250,275 & $3,299,839$ & 399,724 & $3,150,390$ & $3,550,114$ & 252,770 & $3,581,371$ & 430,492 & $3,403,649$ & $3,834,141$
\end{tabular} $\begin{array}{llllllllll}1,824,408 & 1,404,487 & 2,537,368 & 691,527 & 3,228,895 & 1,907,340 & 1,531,425 & 2,666,189 & 772,576 & 3,438,765\end{array}$ $\begin{array}{llllllllll}1,544,465 & 3,079,900 & 2,643,104 & 1,981,261 & 4,624,365 & 1,610,175 & 3,466,511 & 2,820,979 & 2,255,707 & 5,076,686\end{array}$ \begin{tabular}{|lllll|lllll}
444,663 & 805,813 & 640,479 & 609,997 & $1,250,476$ & 455,434 & 948,872 & 688,463 & 715,843 & $1,404,306$
\end{tabular} \begin{tabular}{lllll|lllll}
138,783 & 564,753 & 209,312 & 494,224 & 703,536 & 153,425 & 721,538 & 234,787 & 640,176 & 874,963
\end{tabular} \begin{tabular}{lllll|lllll}
928,911 & $1,271,852$ & $1,191,764$ & $1,008,999$ & $2,200,763$ & 941,729 & $1,357,631$ & $1,214,062$ & $1,085,298$ & $2,299,360$
\end{tabular}

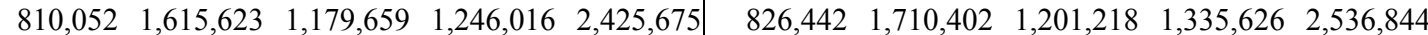
\begin{tabular}{lllll|lllll}
387,143 & $1,698,393$ & 617,049 & $1,468,487$ & $2,085,536$ & 374,852 & $1,842,117$ & 624,389 & $1,592,580$ & $2,216,969$
\end{tabular} \begin{tabular}{lllll|lllll}
837,515 & 911,254 & $1,148,394$ & 600,375 & $1,748,769$ & 875,252 & $1,016,577$ & $1,244,360$ & 647,469 & $1,891,829$
\end{tabular} \begin{tabular}{lllll|lllll}
424,004 & $2,103,324$ & 605,668 & $1,921,660$ & $2,527,328$ & 401,293 & $2,351,929$ & 588,672 & $2,164,550$ & $2,753,222$
\end{tabular} \begin{tabular}{lllll|lllll}
177,398 & 706,526 & 555,220 & 328,704 & 883,924 & 207,383 & 755,263 & 591,135 & 371,511 & 962,646 \\
\end{tabular} \begin{tabular}{|llllll|lllll}
$2,804,093$ & $3,933,231$ & $3,980,448$ & $2,756,876$ & $6,737,324$ & $2,829,007$ & $4,079,968$ & $4,028,128$ & $2,880,847$ & $6,908,975$
\end{tabular} \begin{tabular}{lllll|lllll}
306,033 & $1,250,589$ & 653,060 & 903,562 & $1,556,622$ & 309,457 & $1,348,753$ & 682,394 & 975,816 & $1,658,210$
\end{tabular} \begin{tabular}{lllll|lllll}
665,917 & 670,579 & 919,224 & 417,272 & $1,336,496$ & 631,546 & 722,064 & 899,329 & 454,281 & $1,353,610$ \\
\hline
\end{tabular} 


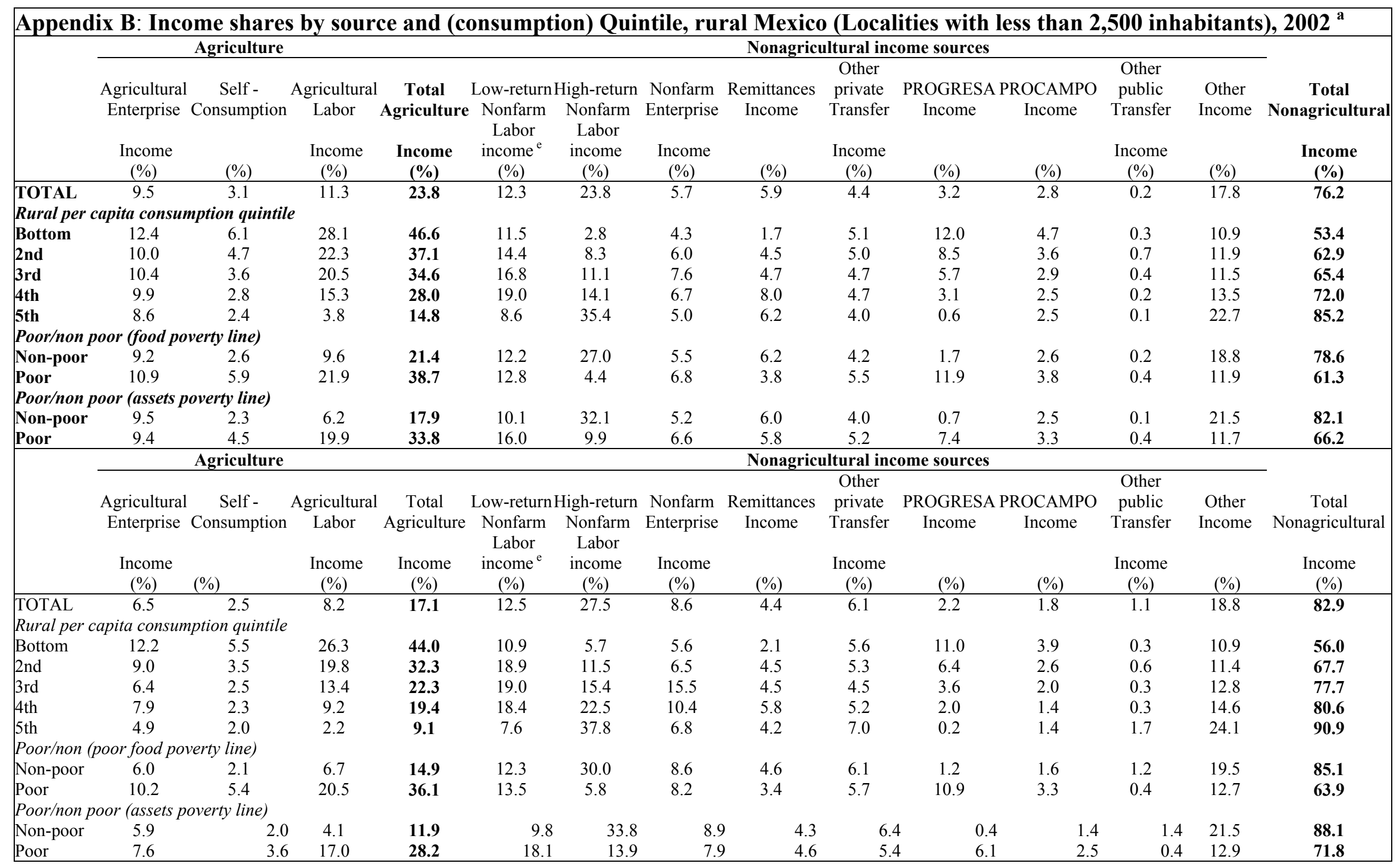




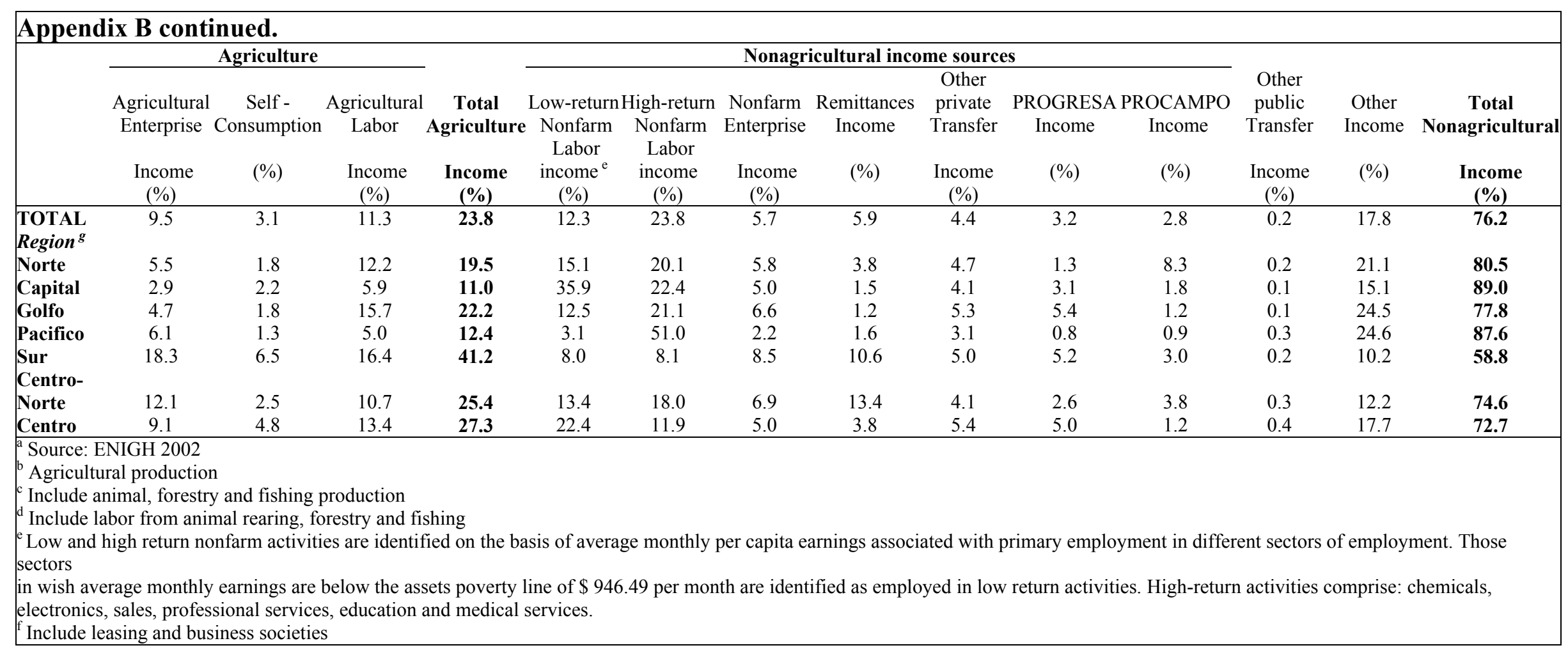

